UNIVERSIDADE ESTADUAL PAULISTA "JÚLIO DE MESQUITA FILHO" FACULDADE DE CIÊNCIAS AGRONÔMICAS CAMPUS DE BOTUCATU

\title{
PRODUÇÃO FAMILIAR E PARÂMETROS DE SUSTENTABILIDADE NO MUNICÍPIO DE BAURU/SP
}

FLÁVIA HOSNE DE FREITAS GALVÃO

Dissertação apresentada à Faculdade de Ciências Agronômicas da UNESP - Campus de Botucatu, para obtenção do título de Mestre em Agronomia (Energia na Agricultura).

BOTUCATU - SP

Dezembro - 2011 
UNIVERSIDADE ESTADUAL PAULISTA "JÚLIO DE MESQUITA FILHO" FACULDADE DE CIÊNCIAS AGRONÔMICAS CAMPUS DE BOTUCATU

\title{
PRODUÇÃO FAMILIAR E PARÂMETROS DE SUSTENTABILIDADE NO MUNICÍPIO DE BAURU/SP
}

\author{
FLÁVIA HOSNE DE FREITAS GALVÃO
}

Orientador: Prof. Dr. José Matheus Yalenti Perosa

Dissertação apresentada à Faculdade de Ciências Agronômicas da UNESP - Campus de Botucatu, para obtenção do título de Mestre em Agronomia (Energia na Agricultura).

BOTUCATU - SP

Dezembro - 2011 
FICHA CATALOGRÁFICA ELABORADA PELA SEÇÃO TÉCNICA DE AQUISIÇÃO E TRATAMENTO DA INFORMAÇÃO - SERVIÇO TÉCNICO DE BIBLIOTECA E DOCUMENTAÇÃO - UNESP - FCA - LAGEADO - BOTUCATU (SP)

Galvão, Flávia Hosne de Freitas, 1984-

G182p Produção familiar e parâmetros de sustentabilidade no município de Bauru/SP / Flávia Hosne de Freitas Galvão. Botucatu : [s.n.], 2011

vii, 85 f. : il. color., tabs., maps.

Dissertação (Mestrado) - Universidade Estadual

Paulista, Faculdade de Ciências Agronômicas, Botucatu, 2011

Orientador: José Matheus Yalenti Perosa

Inclui bibliografia

1. Agricultura - Aspectos ambientais. 2. Agricultura familiar. 3. Desenvolvimento sustentável. 4. Ecologia agrícola. 5. Recursos agrícolas - Conservação. I. Perosa, José Matheus Yalenti. II. Universidade Estadual Paulista "Júlio de Mesquita Filho" (Campus de Botucatu). Faculdade de Ciências Agronômicas. III. Título. 


\section{UNIVERSIDADE ESTADUAL PAULISTA "JÚLIO DE MESQUITA FILHO"}

FACULDADE DE CIÊNCIAS AGRONÔMICAS

CAMPUS DE BOTUCATU

CERTIFICADO DE APROVAÇÂO

TítUlo: "Produçáo familiar e parAmetros de SUSTENTABILIDAde No MUNICIPIO DE BAURU-SP"

ALUNA: FLẢVIA HOSNE DE FREITAS GALVÃO

ORIENTADOR: PROF. DR. JOSÉ MATHEUS YALENTI PEROSA

Aprovado pela Comissão Examinadora

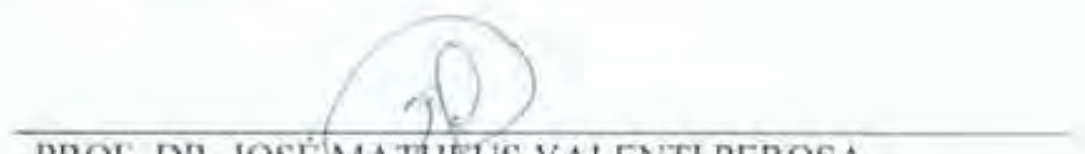

PROF. DR. JOSÉMADHĘU YS YALENTI PEROSA

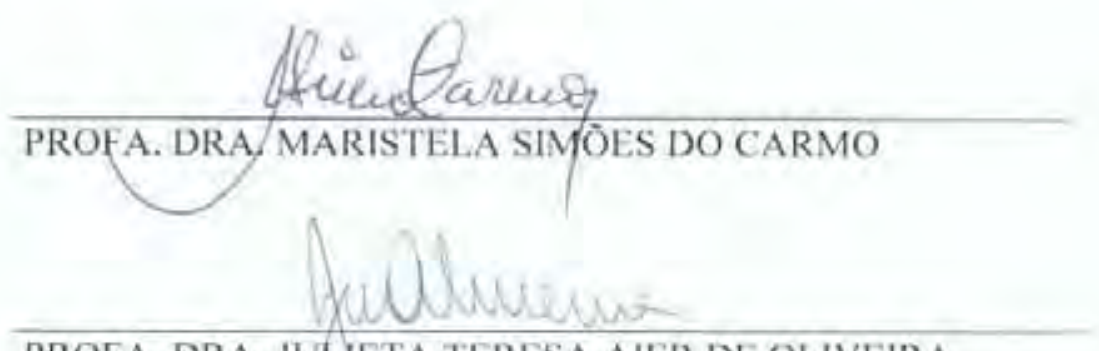

PROFA. DRA. JULIETA TERESA AIER DE OLIVEIRA

Data da Realização: 06 de dezembro de 2011 
"Deus nos fez perfeitos e não escolhe os capacitados, capacita os escolhidos.

Fazer ou não fazer algo, só depende de nossa vontade e perseverança.".

(Albert Einstein)

Dedico este trabalho a Deus, "Em que todos os tesouros da sabedoria e do conhecimento estão ocultos" (Colossenses 2:3). Por ter possibilitado a realização e conclusão deste trabalho.

Ao meu querido marido Wiliam Carlos Galvão pela paciência e companheirismo. A minha família pela compreensão, paciência, incentivo, constante ajuda prestada nos momentos mais importantes e difíceis e compreensão pelas horas ausentes dedicadas a minha formação acadêmica e pessoal.

Em especial aos meus amados pais Creusa Aparecida Hosne e Antonio Teodoro de Freitas

Filho. Ao meu orientador Dr. José Matheus Yalenti Perosa por seu apoio, dedicação, os quais foram fundamentais para o meu amadurecimento intelectual. 


\section{AGRADECIMENTOS}

Há momentos que fazemos de nossas vidas um desafio, desse desafio tiramos à lição de conquistas por toda vida onde sempre contamos com a contribuição de pessoas imprescindíveis.

Primeiramente agradeço a Deus por estar sempre presente em minha vida, meu coração, por me colocar neste caminho longo e difícil, porém gratificante e permitir que tudo o que eu sempre sonhei esteja se realizando dentre outras conquistas que virão.

Agradeço, em especial, minha querida mãe Creusa Aparecida Hosne pela sua primorosa educação, zelo, por minha formação e carinho que me proporcionou a possibilidade de alcançar mais uma etapa de progresso na vida e a meu querido pai Antônio Teodoro de Freitas Filho.

Agradeço a meu marido Wiliam Carlos Galvão, que acompanhou com seu amor, dedicação e compreensão todas as dificuldades e limitações para o desenvolvimento deste trabalho.

Aos meus queridos irmãos Fernanda Hosne de Freitas e Fábio Hosne de Freitas pelo carinho e estímulo nos momentos mais difíceis.

A minha querida prima Marcela Hosne Ardito Ferreira pelo apoio e carinho.

Aos professores Dr. Ângelo Catâneo e Dr. Zacarias Xavier de Barros pela oportunidade dada. $\mathrm{E}$ a todos os professores pelos ricos ensinamentos.

A todas as pessoas que me auxiliaram na realização desta dissertação, em especial, ao meu orientador Professor Dr. José Matheus Yalenti Perosa, que me acolheu e em todas as etapas me guiou e orientou de forma muito incentivadora e pacienciosa.

À Coordenação do Programa de Pós-Graduação em Agronomia: Energia na Agricultura, da Faculdade de Ciências Agronômicas da UNESP, campus de Botucatu - SP. 


\section{SUMÁRIO}

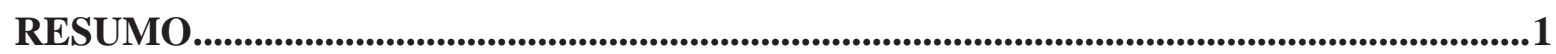

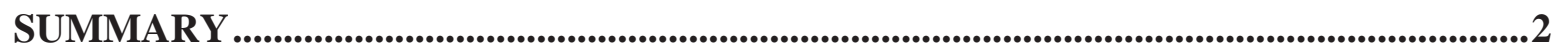

1 INTRODUÇÃO ....................................................................................................................

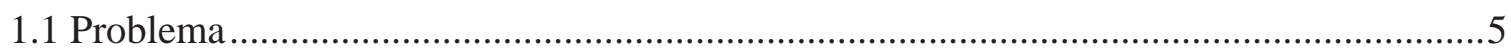

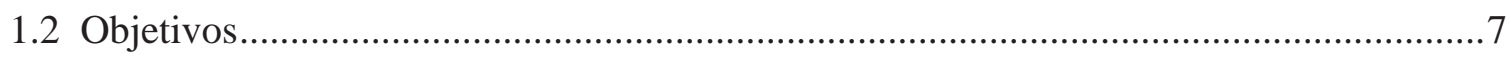

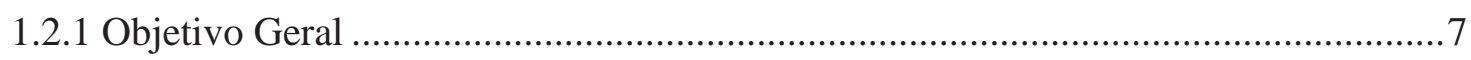

1.2.2 Objetivos Específicos .................................................................................

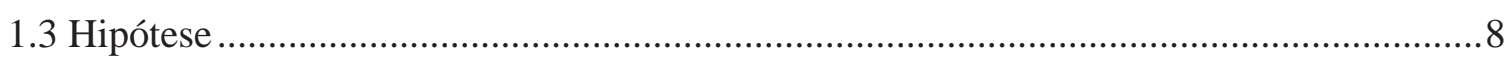

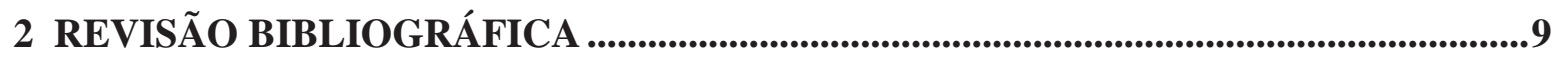

2.1 Agricultura familiar e sua lógica de produção...……………………………………….....9

2.2 Desenvolvimento sustentável ..................................................................................18

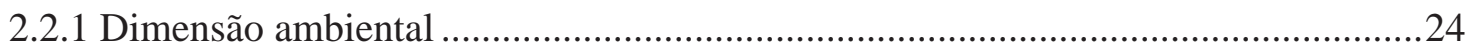

2.2.2 Dimensão Econômica ...........................................................................................25

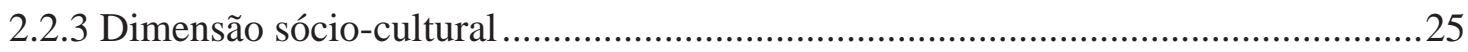

2.3 Agroecologia e tecnologias sustentáveis. ...................................................................26

3 REFERENCIAL DE ANÁLISE....................................................................................39

3.1 Agricultura convencional e agricultura alternativa ...........................................................39

3.2 Tecnologias sustentáveis e agricultura familiar..............................................................42

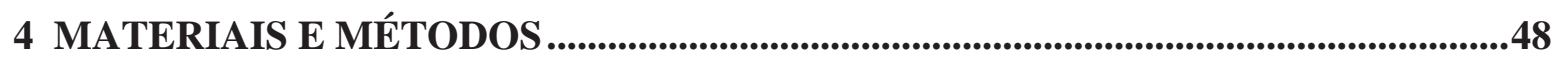

4.1 Caracterização da área de estudo .............................................................................4

4.1.1 Localização Geográfica de Bauru ..........................................................................49

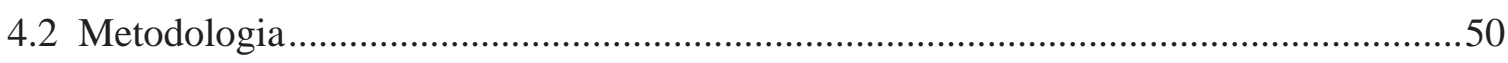

4.3 Dimensões da sustentabilidade na construção de parâmetros ...........................................50

4.3.1 Categoria dimensão ambiental ...........................................................................

4.3.2 Categoria dimensão econômica .................................................................................51

4.3.3 Categoria dimensão sócio-cultural ........................................................................52

4.4 Processo de seleção das propriedades pesquisadas .........................................................52

4.5 Tratamento dos dados .............................................................................................53 


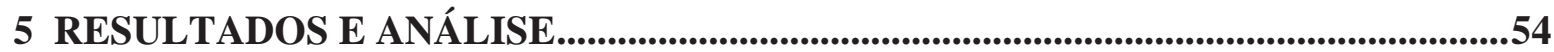

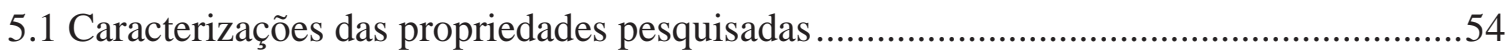

5.2 Resultados relativos à categoria dimensão ambiental ...................................................56

5.3 Resultados relativos à categoria dimensão econômica.......................................................60

5.4 Resultados relativos à categoria dimensão sócio-cultural ............................................62

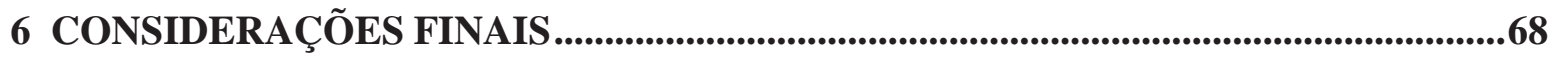

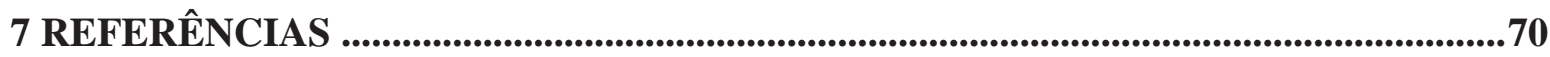

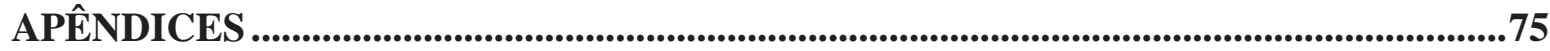




\section{LISTA DE FIGURAS}

Figura 1 - Fluxograma da operacionalização do desenvolvimento rural sustentável................23

Figura 2 - Quadro Agricultura Convencional x Agricultura Ecológica. ...................................40 


\section{LISTA DE TABELAS}

Tabela 1 - Dimensão das propriedades, Bauru, 2011...........................................................55

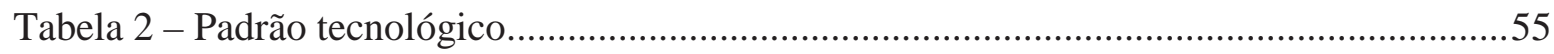

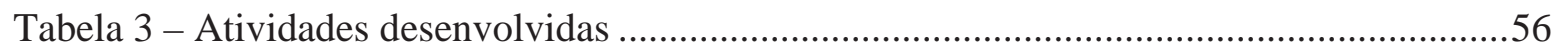

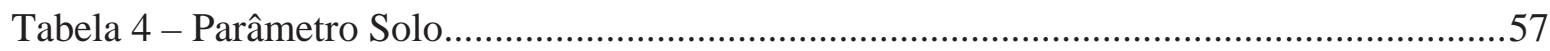

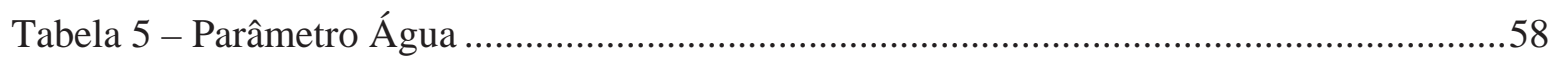

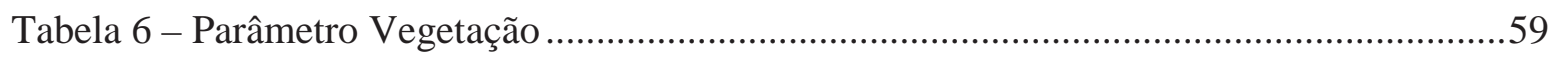

Tabela 7 - Destino da produção ..............................................................................................60

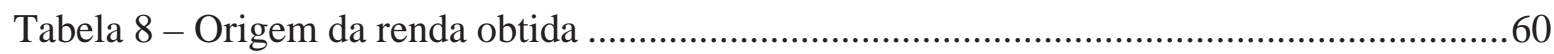

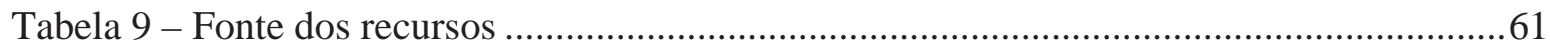

Tabela 10 - Participação familiar na produção ............................................................................62

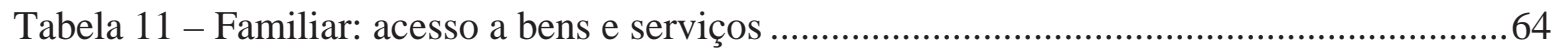

Tabela 12 - Não familiar: acesso a bens e serviços ...............................................................65

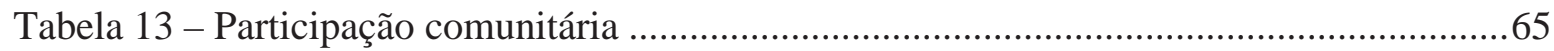

Tabela 14 - Utilização de serviços públicos ................................................................................66

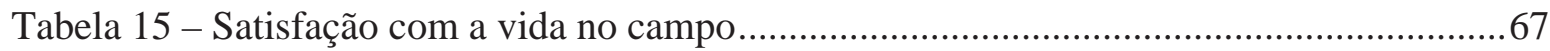




\section{RESUMO}

O objetivo geral do trabalho foi sistematizar e analisar a adequação de produtores familiares e não familiares, bem como a adequação das respectivas lógicas de produção frente a parâmetros de sustentabilidade. O referencial de análise utilizado respalda-se em bases conceituais da agricultura familiar, do desenvolvimento sustentável e tecnologias de produção sustentáveis, identificando parâmetros para análise do grau de adequação das mesmas à lógica de produção. Para análise e discussão das hipóteses do trabalho foi realizada uma pesquisa de campo com produtores familiares e não familiares, de modo a identificar práticas de produção mais condizentes com o conceito de sustentabilidade. A metodologia utilizada constituiu na elaboração e aplicação de questionários através de entrevistas pessoais. Os resultados confirmam a hipótese de que a lógica de produção da agricultura familiar é a mais adequada ao conceito de desenvolvimento sustentável nas suas dimensões ambiental, econômica e sóciocultural.

Palavras-chave: agricultura familiar e desenvolvimento sustentável. 
FAMILIAR PRODUCTION AND PARAMETERS OF SUSTAINABILITY IN BAURU/SP. Botucatu, 2011. 94 pag. Dissertação (Mestrado em Agronomia/Energia na Agricultura) Faculdades de Ciências Agronômicas, Universidade Estadual Paulista - UNESP Author: FLAVIA HOSNE DE FREITAS GALVÃO

Adviser: JOSÉ MATHEUS YALENTI PEROSA

\section{SUMMARY}

The general objective of this study was systematize and analyze the adequacy of familiar and unfamiliar producers, as well as the adequacy of the logic respective of production compared to the parameters of sustainability. The framework of analysis used draws upon in basics concepts of familiar agriculture, sustainable development and technologies of sustainable productions, identifying parameters to analyze the degree to which the same logic of production. To analyze and discussion of this hypothesis was realized a research with familiar and unfamiliar producers, in order to identify practices of production more consistent with the concept of sustainability. The methodology used was development and application of questionnaires through personal interviews. The results confirm the hypothesis that the logical production of familiar agriculture is most appropriate to the sustainable concept in your environmental, economic and socialcultural dimensions.

Keywords: familiar agriculture and sustainable development. 


\section{INTRODUÇÃO}

Este capítulo tem por objetivo apresentar o problema de pesquisa, abordando os objetivos geral e específicos e a hipótese levantada.

A agricultura brasileira se caracteriza por uma diversa heterogeneidade de contextos ambientais, geográficos, econômicos e sócio-culturais, onde cada um apresenta limites e possibilidades para a realização de atividades agrícolas, pecuárias, extrativistas assim como para um conjunto diversificado de ocupações rurais não-agrícolas como o turismo cultural e ecológico (artesanato, agroindústria entre outros). Tal concepção enfoca o rural ressaltando a questão da sua multidimensionalidade, valorizando assim não só os aspectos agrícolas ou econômicos, mas também as suas demais dimensões inerentes ao meio rural.

As unidades de produção de base familiar têm se destacado como objeto de pesquisa por muitos estudiosos da estrutura social e desenvolvimento sustentável do meio rural brasileiro.

Destaca-se que $84,4 \%$ do total de estabelecimentos agropecuários do país pertenciam a grupos de produtores familiares, ocupavam uma área total de 24,3\% contra 75,7\% dos estabelecimentos agropecuários não familiares. Apesar de ter uma ocupação de área menor, ainda assim a participação da agricultura familiar era responsável por 38\% do Valor Bruto da produção gerada no país (BRASIL, 2006). 
Embora haja uma tendência de redução de pessoas ocupadas na agropecuária brasileira como um todo desde 1985, a agricultura familiar foi capaz de reter um maior número de ocupações que a agricultura não familiar. Corresponde a 74,4\% de pessoal ocupado o que representa 12,3 milhões de pessoas contra apenas 4,2 milhões de pessoas na agricultura não familiar. Agricultura familiar é formada por pessoas ocupadas por área total, com 15,3 pessoas por ha, enquanto a agricultura não familiar ocupa apenas 1,7 pessoas por ha. (BRASIL, 2006).

Apesar de a produção familiar cultivar uma área menor em lavouras (17,7 milhões de ha) e pastagens (36,4 milhões de ha) a agricultura familiar é a principal fornecedora de alimentos básicos para a população brasileira e é importante fornecedora de proteína animal (BRASIL, 2006).

Entre 1996 e 2006 cresceu o valor bruto da produção (VBP) da produção da agricultura familiar e sua participação no VBP total. Cresceu em âmbito nacional, de 38 para $40 \%$ e em todas as regiões do país, especialmente no Norte e Nordeste, onde o crescimento foi de $11 \%$ e $9 \%$ respectivamente. Ressalta-se que a agricultura familiar gera um VBP de R\$ 677/ha a qual é 89\% superior ao gerado pela agricultura não familiar (R\$ 358/ha). (BRASIL, 2006).

Esses dados quantitativos seriam suficientes para justificar a tamanha importância de estudos e pesquisas que subsidiem a implementação de políticas públicas visando o fortalecimento da agricultura familiar. Destaca-se a possibilidade da criação de oportunidades de trabalho local, reduzindo assim o êxodo rural. Outro fator relevante é a diversificação da atividade econômica o que visa promover o desenvolvimento sustentável dos municípios.

A agricultura familiar no Brasil é extremamente heterogênea e inclui, desde famílias muito pobres até famílias com grande dotação de recursos. Embora muitas vezes a utilização da categoria "agricultura familiar" seja útil, comumente utilizada e desejável para fins de formulação política, é preciso tratar os agricultores familiares como diferentes entre si, no que diz respeito à geração e difusão de tecnologias alternativas agroecológicas sustentáveis e que seja adequada a sua lógica de produção. 
Essa dissertação tem como tema central analisar a participação da agricultura familiar no contexto de um desenvolvimento rural sustentável. Nesse sentido, parâmetros que conformam a lógica de produção familiar foram utilizados para análise da maior ou menor adequação da mesma no desenvolvimento rural sustentável.

A construção do referencial teórico para esta análise teve por base conceitos sobre desenvolvimento sustentável, agroecologia e tecnologias alternativas, identificando obstáculos e mudanças necessárias para transformar paradigmas existentes. Para a compreensão e dimensionamento do ator social a ser estudado buscou-se identificar os vários conceitos de agricultura familiar.

Foi utilizada como ferramenta a pesquisa de campo com agricultores familiares e não familiares no município de Bauru - SP, bem como entrevistas em órgãos públicos do município, de modo a identificar e qualificar o atual modo de produção e desenvolvimento destes produtores no município.

\subsection{Problema}

Teixeira (2005) e Oliveira (2000) relatam que o setor agrícola brasileiro passou por alterações ao longo dos anos, algumas com destaque no desenvolvimento através da industrialização, ocorrido a partir dos anos cinqüenta do século passado, colocando o setor numa posição secundária e subalterna. Neste sentido, levou a que a própria produção científica se alicerçasse nas teses da funcionalidade da agricultura familiar na oferta de alimentos e matérias-primas para viabilização do projeto de modernização do País.

Esse processo de modernização fomentou uma dualidade na agricultura brasileira. De um lado, propiciou a capitalização e incrementos significativos na produção e produtividade e, ao mesmo tempo, exclusão social, aumento da concentração fundiária e do êxodo rural, alteração da estrutura do emprego e no tratamento diferenciado de produtos, regiões e tipos de produtores por parte das políticas agrícola e agrária.

Já no início dos anos setenta, a difusão internacional da chamada "questão ambiental", com as "crises do petróleo, vinham apontando o esgotamento dos recursos naturais, assim um novo desafio foi lançado para a agricultura. Os sérios problemas 
de degradação ambiental e os riscos de sobrevivência do planeta às gerações futuras evidenciaram a necessidade da construção de um novo paradigma de desenvolvimento, no qual o crescimento econômico e a garantia de condições dignas de vida à população passassem a ser enfocados nos limites da sustentabilidade do meio ambiente (TEIXEIRA, 2005; OLIVEIRA, 2000).

Os maiores problemas ambientais foram relacionados à poluição urbano-industrial e aos padrões de consumo das sociedades desenvolvidas, mesmo assim, a agricultura mostrou um destacado espaço nas discussões sobre sustentabilidade. Pode-se refletir que este fato ocorreu porque a agricultura é a que representa a atividade produtiva que mais aproxima o homem da natureza.

Vive-se um momento de pleno questionamento a tudo que o homem faz ou pretende fazer e cujas conseqüências podem ou não agredir o meio ambiente e, na seqüência, a si mesmo. A agricultura familiar torna-se, desta forma, de extrema importância dentro deste novo modo de ver o mundo e a sua preservação, e por conseqüência a preservação do seu saber, aliada a uma geração de valor pelo seu trabalho, torna-se fundamental.

Neste contexto, como enfatizam Carmo (1998) e Oliveira (2000), a produção familiar poderia, dada as suas características, representar um espaço social propício para o desenvolvimento de uma agricultura ambientalmente sustentável.

O ambiente institucional conformado por padrões e normas formulados pelo Estado, com intuito de melhorar a qualidade dos bens produzidos tanto por agricultores familiares como para os produtores não familiares, não levam em consideração características específicas da agricultura familiar. Esse é um problema para o agricultor familiar visto que o mesmo, em sua maioria, não dispõe de recursos estruturais, financeiros e tecnológicos para que possa e consiga adequar-se às novas regras e padrões.

Neste ambiente institucional, o agricultor familiar teria dificuldade de participar de um mercado onde produtores capitalizados, por disporem de maiores recursos financeiros e físicos, poderiam demonstrar melhores condições à adoção de práticas agrícolas ambientais e rentáveis, como rotação de culturas, adubação orgânica, conservação e 
recuperação de solos, formação e recuperação de matas ciliares, controle integrado de pragas, entre outras.

Neste sentido, torna-se importante a discussão sobre o espaço da agricultura familiar como alternativa ao padrão técnico-produtivo intensivo em energia, capital e tecnologia. Essa discussão deve dar-se não apenas pela óptica tecnológica, mas, fundamentalmente, no campo dos interesses relativos à construção de um projeto mais amplo de sociedade, a sustentabilidade ${ }^{1}$.

Uma vez que mesmo no atual padrão agrícola dominante, a produção familiar brasileira mantém-se tecnologicamente relevante e dinâmica na geração de renda e emprego, cabe argumentar se não seria maior seu espaço de reprodução num projeto maior de sociedade, sob a ótica da sustentabilidade.

\subsection{Objetivos}

\subsubsection{Objetivo Geral}

Analisar a adequação da lógica de produção de produtores familiares e não familiares a parâmetros de sustentabilidade.

\subsubsection{Objetivos Específicos}

a) Elencar parâmetros de sustentabilidade como referência para a produção familiar e não familiar;

b) Explicitar a lógica da produção familiar;

c) Associar a lógica de produção de produtores e sua aderência aos indicadores de sustentabilidade.

\footnotetext{
${ }^{1}$ Pires (1998) relata que a sustentabilidade envolve noções de estabilidade, complementaridade, reciclagem de energia e equilíbrio dinâmico. Buarque (1999) completa que o desenvolvimento sustentável é o caminho de mudança social e elevação das oportunidades da sociedade, compatibilizando, no tempo e no espaço, o crescimento e a eficiência econômica, a conservação ambiental, a qualidade de vida e a equidade social.
} 


\subsection{Hipótese}

A produção familiar dada suas características disporia de condições mais favoráveis quanto ao atendimento dos requisitos do manejo equilibrado dos agroecossistemas, da ocupação da força de trabalho e da diversidade, preconizados pelo paradigma da sustentabilidade. 


\section{REVISÃO BIBLIOGRÁFICA}

Este capítulo tem por objetivo apresentar as bases conceituais que orientaram a estrutura do presente trabalho. Contempla duas partes.

A primeira parte fez-se uma discussão sobre agricultura familiar, destacando-se sua definição conceitual e a análise de sua lógica de produção, bem como sua importância no desenvolvimento recente do país.

Da mesma forma, na segunda parte fez-se uma revisão bibliográfica sobre desenvolvimento sustentável e as possibilidades da agricultura familiar neste contexto.

\subsection{Agricultura familiar e sua lógica de produção}

O termo "agricultura familiar" apresenta conceitos variados na literatura científica brasileira e mundial. Encontra-se agricultura de subsistência, agricultura dos pequenos agricultores ou agricultura de renda baixa. Mas o que de fato representa a agricultura familiar? Um ponto de partida para a conceituação da agricultura familiar pode ser encontrado na citação a seguir:

A definição de agricultura familiar para Lamarche (1993) e (1998) bem como para Wanderley (1996) corresponde à unidade de produção agrícola onde a família é a 
proprietária dos meios de produção ao mesmo tempo em que assume o trabalho no estabelecimento produtivo e organiza a produção. (PINHEIRO, 2004, p. 84).

Na legislação brasileira a definição de propriedade familiar consta no inciso no artigo $3^{\circ}$, estabelecido pela Lei $\mathrm{n}^{\circ} 11.326$ de 24 de julho de 2006 com a seguinte redação: "Para os efeitos desta Lei, considera-se agricultor familiar e empreendedor familiar rural aquele que pratica atividades no meio rural, atendendo, simultaneamente, aos seguintes requisitos: I - não detenha, a qualquer título, área maior do que 4 (quatro) módulos fiscais; II utilize predominantemente mão-de-obra da própria família nas atividades econômicas do seu estabelecimento ou empreendimento; III - tenha renda familiar predominantemente originada de atividades econômicas vinculadas ao próprio estabelecimento ou empreendimento; IV dirija seu estabelecimento ou empreendimento com sua família".

O conceito de Agricultura Familiar no Brasil surgiu na década de 1990 como características de um grupo ou uma nova categoria social. Schmeider (2003) mostra que a Agricultura Familiar surgiu em meio a movimentos sociais e mudanças políticas importantes.

Segundo Buainaim et al. (2000) existem duas condições que podem caracterizar a Agricultura Familiar. Uma é que a direção da propriedade e dos trabalhos realizados deve ser feita pelo produtor rural e a outra é que a mão-de-obra utilizada deve ser em maioria por parte familiar.

Segundo Programa de Fortalecimento da Agricultura Familiar - Pronaf são considerados agricultores familiares os que são caracterizados a partir dos seguintes critérios: possuir $80 \%$ da renda familiar originária da atividade agropecuária; deter ou explorar estabelecimentos com área de até 4 módulos fiscais; explorar a terra na condição de proprietário, meeiro, parceiro ou arrendatário; utilizar mão-de-obra exclusivamente familiar, podendo manter até dois empregados permanentes, sendo admitida a ajuda eventual de terceiros; residir no imóvel ou em aglomerado rural ou urbano próximo e possuir uma renda anual de R\$ 6.000,00 até R\$ 110.000,00. (Plano safra 2011/2012).

Nos estudos sobre a produção familiar localizam-se diferentes critérios que delimitam o universo dos agricultores familiares (VEIGA, 1991; ABRAMOVAY, 1992; GUANZIROLI et al., 2001 apud BASSO, 2007). A principal característica dos produtores familiares em relação aos produtores não familiares é o predomínio do trabalho 
essencialmente familiar. Guanziroli et al. (2001), define que os produtores familiares são aqueles que atendem os seguintes quesitos: a) a direção dos trabalhos é exercida pelo produtor; b) o trabalho familiar é superior ao trabalho contratado; c) unidades de produção cujo tamanho é determinado pelo que a família pode explorar com base em seu próprio trabalho associado à tecnologia de que dispõe (BASSO, 2007).

Existem agricultores familiares cuja formação para a atividade agrícola não se deu pela transmissão de conhecimentos de geração para geração. Como exemplos têmse os egressos do meio urbano e que se tornam, por diversos motivos, produtores rurais. Este tipo de produtor é identificado diferentemente daquele que teve a sua história produtiva sempre ligada ao campo. Karam (2002) estabelece a diferença e conceitua especificamente o produtor que se dedica à agricultura orgânica. O agricultor(a) orgânico(a) tradicional é o que tem sua trajetória total de vida no meio rural, e, o(a) agricultor(a) orgânico(a) neo rural é aquele(a) cuja trajetória de vida foi, até recentemente, vivenciada no mundo urbano.

Lamarche (1993) apud Trentin e Wesz Junior (2005) apresentam um conceito genérico: "A agricultura familiar não é um elemento da diversidade, mas contém nela mesma, toda a diversidade." Esta diversidade vai se caracterizar conforme Lamarche (1993, p. 22) apud Karam (2002): “[...] segundo as diferentes lógicas existentes nas unidades agrícolas desde aquelas regidas somente pela demanda da família até aquela onde a produção norteia-se por uma racionalidade empresarial capitalista."

Lamarche coord. (1994 apud OLIVEIRA, 2000) aponta de forma interessante a interação entre as lógicas familiares e o grau de dependência externa, expressas em eixos cartesianos o que permitiu a construção de quatro modelos assim denominados: empresa, empresa familiar, camponês e exploração familiar moderna. Modelos estes que destacam as lógicas sociais de funcionamento da moderna agricultura familiar em níveis mundiais.

Os modelos empresa e empresa familiar caracterizam-se pela grande dependência das explorações em relação ao nível tecnológico da produção (agricultores muito tecnificados com produção voltada para o mercado de massa), aos investimentos freqüentes visando à melhoria dos meios de produção e, ao consumo, particularmente no atendimento às necessidades alimentares da família. 
A diferença entre os modelos destaca-se quanto ao espaço e no papel atribuído à família.

Na empresa, a família não ocupa um espaço focado na tomada de decisão e na definição de estratégias; a terra é um instrumento de trabalho; a família participa pouco ou quase nada nas tarefas agrícolas e as ambições futuras não estão necessariamente ligadas à reprodução da exploração.

Na empresa familiar ocorre o inverso, a família na maior parte das vezes se foca na tomada de decisões; a terra é um patrimônio familiar que assegura sua continuidade; a terra para cultivo alimentar garante a sobrevivência mínima; a família se destaca no trabalho agrícola; e, todos os projetos para o futuro são organizados para satisfazer os interesses de seus membros.

O modelo camponês caracteriza-se por explorações sobre fundamentos essencialmente familiares e fortemente independentes em relação ao mercado. A função revelada de sobrevivência é marcante no modelo camponês. Nota-se a vontade de preservação e de crescimento do patrimônio familiar.

O último modelo é a exploração familiar moderna. Enquadram-se nele cerca de $25 \%$ do total de explorações pesquisadas e mais de $45 \%$ das brasileiras. Ao mesmo tempo em que é pouco familiar também conserva sua independência em relação ao mercado.

Neste contexto o agricultor familiar moderno permanece bastante preso à noção de patrimônio (há o desejo de desenvolver o patrimônio familiar, do qual é herdeiro, e deixá-lo para seus sucessores). O trabalho familiar ocupa um espaço menor na realização das tarefas agrícolas e o uso de mão-de-obra externa, muito mais temporária que permanente, está presente em todas as explorações deste grupo. Do ponto de vista das lógicas produtivas, aparentemente, o agricultor familiar moderno procura preservar certo grau de autonomia, "afastando-se" dos extremos (modelos camponês e empresas); observa-se um reduzido engajamento financeiro e uma forte retração em relação ao mercado, já que a maior parte da produção é reutilizada para as necessidades da exploração ou para o auto-consumo das famílias; ela jamais é totalmente comercializada. 
Abramovay et al. (1995) apud Oliveira (2000) montou uma estratificação baseada na relação entre uso do trabalho familiar e não familiar no interior dos estabelecimentos rurais do estado de São Paulo, em termos de tempo de trabalho.

Foram elaboradas quatro classes de imóveis: a classe 1, composta por estabelecimentos que não tinham qualquer forma de trabalho assalariado; a classe 2, por aqueles produtores que empregavam o trabalho assalariado numa proporção de tempo menor que do trabalho familiar; na classe 3 a quantidade de trabalho assalariado era superior ao familiar; e, na classe 4, não ocorria nenhum tipo de trabalho familiar.

A partir desta estratificação foram relacionados dados relevantes sobre: área, produção, dias homens empregados, participação na oferta de cada produto e participação no total da produção agropecuária paulista. Os resultados demonstraram a predominância econômica da agricultura patronal (classes 3 e 4) pois congregavam pouco mais de um terço dos imóveis, respondiam por mais de dois terços do valor da produção agropecuária paulista e por $60,24 \%$ do conjunto de dias-homens empregados. (ABRAMOVAY et al., 1995 apud OLIVEIRA, 2000).

Esses dados evidenciaram que os agricultores familiares demonstram maior eficiência que os patronais, produzindo proporcionalmente mais com menos recursos.

Buainain e Romeiro (2000) destacam que a agricultura familiar desenvolve de modo geral sistemas complexos de produção os quais não se focam em somente um segmento e sim diversificam entre criações animais, várias culturas, e transformações primárias, tanto para o consumo da família como comercialização. Sob amplo estudo quanto a sistemas de produção familiares no Brasil, os autores afirmam que os produtores familiares apresentam com freqüência as características seguintes:

- Diversificação: quanto maior for à diversificação dos sistemas, menores serão os riscos que os produtores podem enfrentar, destaca-se que esta característica foi a mais localizada na maioria dos estabelecimentos familiares estudados pelos autores.

- Estratégia de Investimento Progressivo: a maioria dos agricultores familiares baseiam-se suas estratégias de "acumulação" e de aumento de produtividade em pequenos volumes de capital os quais podem ser guardados de forma progressiva, como 
exemplo pode-se destacar as cabeças de gado acumulados ao longo dos anos, as máquinas e implementos usados, os equipamentos de irrigação adquiridos progressivamente, entre outros).

- Combinação de Subsistemas Intensivos e Extensivos: os produtores familiares adotam de forma geral sistemas de atividades intensivas que conjugam trabalho e terra, com atividades mais extensivas. Assim quanto maior for a disponibilidade de área, maior será a participação de sistemas extensivos. Ao inverso, quanto menor a disponibilidade de área, maior a importância relativa dos cultivos altamente exigentes em mão-de-obra e altamente intensivos no uso do solo como horticultura irrigada e fruticultura.

- Grande Capacidade de Adaptação: os agricultores familiares possuem relevante capacidade de adaptação a ambientes em transformação rápida, devido à crise de produtos tradicionais, mudanças mais gerais da situação econômica do pai e ou emergência de novos mercados. Vale citar outra característica presente cada vez mais na agricultura familiar brasileira é a "pluriatividade".

O autor Schneider (2003), cita a seguinte definição do termo pluriatividade "A pluriatividade permite reconceituar a propriedade como uma unidade de produção e reprodução, não exclusivamente baseada em atividades agrícolas. As propriedades pluriativas são unidades que alocam o trabalho em diferentes atividades, além da agricultura familiar. [...]. A pluriatividade, portanto, refere-se a uma unidade produtiva multidimensional, onde se pratica a agricultura e outras atividades, tanto dentro como fora da propriedade, pelas quais são recebidos diferentes tipos de remuneração e receitas (rendimentos, rendas em espécies e transferências)". Na agricultura familiar, a junção entre a mão-de-obra familiar agrícola e não-agrícola está relacionada à manutenção do estabelecimento agrícola proporcionando a permanência de sua reprodução socioeconômica. O trabalho agrícola e nãoagrícola realizados de forma complementar pelos membros da família que residem na propriedade, se deve a pouca disponibilidade de terra e às dificuldades de modernização tecnológica, o que compromete sua renda, obrigando essas pequenas unidades a buscar uma alternativa complementar de renda.

Wanderley (1995) cita que o trabalho familiar externo se torna uma necessidade estrutural, isto é, a renda obtida no trabalho externo a produção vem a ser, em sua maioria, indispensável para o auxílio e reprodução não só da família como do próprio 
estabelecimento familiar. Assim, destaca-se que o trabalho extra-agrícola, tem duas funções sociais: a primeira é de complementar a renda da família e a segunda diz respeito à permanência dessas famílias no meio rural, garantindo assim a propriedade do bem rural.

Schneider (1999) cita que além das estratégias de ocupar a mão-deobra familiar em atividades agrícolas e não-agrícolas, os agricultores familiares conciliam a mão-de-obra familiar com a contratada (permanente ou temporária) nas atividades de produção dentro de suas propriedades, isso ocorre quando há carência de mão-de-obra familiar, como exemplo em casos como quando os filhos não estão em idade de participar das atividades agrícolas, neste caso a mão-de-obra familiar perdeu seu potencial produtivo (predominância de idosos) e quando a propriedade pratica atividade produtiva altamente intensiva em mão-de-obra.

O mesmo autor revela que a composição das estratégias da agricultura familiar depende de aspectos importantes que compõem o meio no qual os agricultores familiares estão inseridos. Assim, ao se definir a agricultura familiar contemporânea, devemse levar em conta todas as formas que essa categoria social apresenta, seja ela baseada no trabalho familiar não-agrícola (pluriatividade) ou com a participação do trabalho assalariado, mas que a essência da mão-de-obra familiar (agrícola ou não-agrícola) seja preservada.

Veiga et al. (2001) ressaltam a importância da agricultura familiar no meio rural brasileiro, pois possuem região rural a qual terá um futuro tanto mais dinâmico quanto maior for à capacidade de diversificação da economia local impulsionada pelas características de sua agricultura.

Com base nos dados do Censo Agropecuário do IBGE de 1995/96, Guanziroli e Cardim (2000), verificaram que quando se calculou a Renda Total por hectare, a agricultura familiar mostrava-se muito mais eficiente que a patronal, produzindo uma média de $\mathrm{R} \$ 104,00 /$ ha/ano contra apenas $\mathrm{R} \$ 44,00 /$ ha/ano dos agricultores patronais. Segundo os autores, essa constatação refere-se ao rendimento do fator terra, em cujo uso os agricultores familiares revelaram-se mais eficientes, utilizando uma proporção maior de sua área em sistemas intensivos, tentando aproveitar ao máximo sua área total, isso porque a terra é um fator limitante para ele, e por isso tem que intensificar seu uso. Os patronais, pelo contrário, têm terra abundante, e por este motivo a tendência é a utilização da melhor parte de sua terra 
com um sistema intensivo, no qual ele vai ter provavelmente maior eficiência técnica e vai destinar o restante da área a um sistema extensivo.

Quando a eficiência é medida em relação ao uso do fator trabalho, os patronais fazem um uso mais intensivo, já que esse é um fator escasso para essa categoria, e os familiares fazem um uso mais extensivo, já que possuem pessoas da família subempregada, e precisam alocá-la nos trabalhos agrícolas.

A agricultura familiar tem um papel relevante no cenário nacional. Frente sua importância, a exploração agrícola familiar recebeu incentivos por intermédio de políticas públicas basicamente observadas em três vertentes que se complementam: crédito rural, apoio à infra-estrutura regional e capacitação dos agricultores. Salienta-se que a maioria dos agricultores busca na política de crédito rural um de seus maiores incentivos. Assim, destacou-se o Programa Nacional de Fortalecimento da Agricultura Familiar (Pronaf).

Guanziroli et al. (2001 apud BASSO, 2007), ao trabalhar com dados provenientes do Censo Agropecuário 1995/1996, destacaram a existência de 4.859.864 estabelecimentos rurais no Brasil, ocupando uma área de 353,6 milhões de hectares. Desse total, 4.139.369 foram classificados como estabelecimentos familiares, ocupando uma área de 107,8 milhões de ha e recebendo apenas R\$ 937 milhões de financiamento rural. Os agricultores familiares representavam, portanto, $85,2 \%$ do total de estabelecimentos, ocupando 30,5\% da área total e sendo responsáveis por 37,9\% do Valor Bruto da Produção Agropecuária Nacional, recebendo apenas 25,3\% do financiamento destinado à agricultura.

Levantamento do Ministério do Desenvolvimento Agrário (MDA), encomendado junto à Fundação Instituto de Pesquisas Econômicas (FIPE), revelou que, em 2003, a agricultura familiar respondeu por 10,1\% do Produto Interno Bruto (PIB) - a soma de todas as riquezas do Brasil. A pesquisa revelou também que o PIB do setor cresceu R \$13,4 bilhões no ano passado, um incremento de 9,37\% em relação a 2002, só na agricultura familiar. Esta foi a primeira vez que o governo federal mediu o impacto econômico da atividade praticada exclusivamente por agricultores familiares (INTERLEGIS, 2007 apud BASSO, 2007).

Agricultura familiar não é sinônimo de trabalho familiar. O que distingue a maioria das formas sociais de produção como familiar é o papel preponderante da 
família como estrutura fundamental de organização da reprodução social através da formulação de estratégia (conscientes ou não) familiares e individuais que remetem diretamente à transmissão do patrimônio material e cultural (a herança) e à transmissão da exploração agrícola (a sucessão). No entanto, não são raras as unidades de produção agrícola sustentadas exclusivamente pelo trabalho do casal ou por apenas 1 dos membros do casal. A autonomização dos membros da família em relação ao mercado de trabalho é uma tendência confirmada em diversos países da Europa, na França sobre tudo, e que vem se afirmando também no Brasil.

Os agricultores familiares conviveram e convivem com vários limites ao seu desenvolvimento, definidos pelas dificuldades de acesso à propriedade da terra, pelo caráter parcial e incompleto de modernização tecnológica e pela necessidade de recorrer ao trabalho assalariado externo, seja para completar a força de trabalho familiar demandada pela exploração da unidade produtiva, seja pelo seu próprio assalariamento, ou de familiares, para ingresso de renda complementar.

No entanto, estratégias produtivas como produção para auto-consumo ou assalariamento fora da propriedade, impondo-lhe a condição de trabalhador rural, longe de representarem sinais de fragilidade ou de decomposição da própria condição de produtor agrícola, constituem-se elementos que conferem maior segurança aos agricultores diante de situações de risco, valorizando sua condição de agricultor e de manutenção do patrimônio familiar, especialmente a terra. Ademais, sua permanência na condição de agricultor fica objetivamente comprovada pelo importante papel desempenhado na ocupação da força de trabalho rural, na geração de renda e eficiência técnico-econômica das exploração agrícolas familiares.

Assim, a maioria das definições de agricultura familiar baseia-se na mão-de-obra utilizada, módulos, na direção dos trabalhos e na renda gerada pela atividade agrícola.

Para o presente trabalho adota-se a definição operacional do Pronaf e a conceituação científica onde, resumidamente, agricultura familiar é entendida como uma unidade de produção onde trabalho, terra e família estão intimamente relacionadas: ao mesmo 
tempo em que é proprietária dos meios de produção, a família assume o trabalho no estabelecimento.

Para analisar como essa lógica de produção pode ser a mais ou menos adequada a um projeto de agricultura sustentável, faz-se necessário uma explicitação sobre desenvolvimento sustentável.

\subsection{Desenvolvimento sustentável}

A partir dos anos de 1990, nasce uma consciência das limitações dos recursos naturais, antes vistos como inesgotáveis e infinitos. Essa constatação impõe a necessidade de mudanças nas falsas verdades, como a disponibilidade infinita de recursos. Um conceito formulado, como aquele que permite responder as necessidades presentes sem comprometer a capacidade das gerações futuras em responder as suas próprias necessidades, agora proposto como desenvolvimento sustentável, não esta fechado, uma vez que "[...] ainda não conta com um atributo teórico e prático totalmente definido.” (PIRES, 1998, p. 12).

O relatório "Nosso Futuro Comum" da Comissão Mundial Sobre o Meio Ambiente e Desenvolvimento da ONU (1988 apud OLIVEIRA, 2000), criada em Assembléia Geral de 1983, foi o alerta oficial mais contundente sobre a indispensabilidade de se pensar as novas bases para o desenvolvimento da humanidade, garantindo a satisfação das necessidades do presente sem comprometer a capacidade das gerações futuras em atender suas próprias necessidades. Era preciso, então, incluir o fator preservação ambiental à equação do desenvolvimento até então formada pela necessidade de crescimento econômico e busca da eqüidade social, esta, ainda que, apenas no discurso.

Ficava claro que crescimento populacional, segurança alimentar, consumo energético e poluição eram temas que precisavam ser discutidos de forma global. As projeções estatísticas indicavam, por um lado, a impossibilidade de manutenção dos níveis de consumo nos países avançados e, por outro, o agravamento da situação de miséria e insegurança alimentar dos países do Terceiro Mundo.

Os conceitos formulados durante as décadas de 1970 e 1980 ajudaram a elucidar o que seria desenvolvimento sustentável. Um dos primeiros conceitos formulado 
por organizações partiu do documento elaborado em 1980 pela União Internacional para a Conservação da Natureza (UICN), que juntamente com a Conferência de Ottawa, de 1986 estabelece os seguintes quesitos:

a) Integração da conservação e do desenvolvimento;

b) Satisfação das necessidades humanas básicas;

c) Alcance da equidade e da justiça social;

d) Provisão da autodeterminação social e da diversidade cultural; e

e) Manutenção da integração ecológica.

Esses quesitos fornecem uma direção para a formulação de conceitos mais apropriados para desenvolvimento sustentável. Embora avancem nesse aspecto, não caracteriza um conceito fechado.

Pires (1998) relata que a sustentabilidade envolve noções de estabilidade, complementaridade, reciclagem de energia e equilíbrio dinâmico. Buarque (1999) completa que o desenvolvimento sustentável é o caminho de mudança social e elevação das oportunidades da sociedade, compatibilizando, no tempo e no espaço, o crescimento e a eficiência econômica, a conservação ambiental, a qualidade de vida e a equidade social. Ambos os autores supracitados apresentam uma incredulidade na mudança do modelo atual, contudo ambos afirmam que pode ser possível essa mudança. Porém Buarque (1999) enfatiza que esta possível mudança de visão e comportamento [...] "nem sempre é consciente e está, normalmente, carregada de dificuldades e resistências estruturais".

Outro ponto de discussão dos mesmos autores é o que diz respeito à transição para alcançar a sustentabilidade. Para Pires (1998) é necessário o estabelecimento de estratégias de transição. Esses dependerão do grau de envolvimento dos atores sociais interessados na mudança de paradigma. E Buarque (1999) afirma que é necessário um planejamento para que sejam tomadas decisões pela sociedade em relação ao futuro, envolvendo, portanto, escolhas entre alternativas e definição de objetivos coletivos que orientam a ação.

A proteção do meio ambiente não é, em si, um único fator de desenvolvimento sustentável. Como analogia a essa afirmação pode-se refletir com um exemplo prático: para proteção e conservação de um determinado ambiente ou área podem-se 
solicitar a desapropriação das terras e proibir sua utilização pelas pessoas que dali tiram seu sustento, porém esse ato levaria a um conflito de opiniões sobre a criação dessa área de conservação, já que em contrapartida causaria um problema, até maior, do que o impacto ambiental ali provocado.

Kareiva e Marvier (2007) afirmam que as relações do homem com a natureza são de suma importância e a separação total entre os dois provocaria também um desequilíbrio ambiental. Sendo assim, fazia-se necessária a desocupação de pessoas dessas áreas, mas segundo o artigo, é muito importante a relação entre os moradores e o meio ali presente, tanto para o ambiente quanto, também, para os moradores. Então, é essa relação estabelecida entre homem e natureza que, se bem orquestrada, torna-se um desenvolvimento sustentável.

A capacidade de se ajustar é, talvez, o principal fator de desencadeamento do desenvolvimento sustentável. Se ajustar às características presentes no meio ambiente, onde fatores como biodiversidades, clima, recursos naturais e reaproveitamento são de imensa importância, porque definem a forma de extração e a velocidade de recuperação do meio, frente ao seu uso, estimulam a sociedade ali presente. Suas relações, necessidades e problemas, que vão desde sua infra-estrutura, até a educação que pode ser a parte mais importante do processo de mudança de valores têm a tendência de se adaptar a estas pressões ambientais.

De acordo com Guimarães (2001), é lamentável que, em função da rapidez da modernização, a economia tenha deixado de estudar os meios para o bem estar social e se transformado em um fim em si mesmo, uma ciência na qual tudo o que não tem valor monetário e tudo a respeito de que não se pode estabelecer um preço, não tem valor. Essa afirmação deu uma visão do que realmente tem se tornado a sociedade, em algo onde o ter, o possuir é mais importante do que o ser e o modo de pensar já não é mais voltado a um crescimento pessoal, mas um modelo pré-estabelecido pelo mercado.

Como pode ser observado, a partir das reflexões, o crescimento econômico dos sistemas de produção atual, baseado na lógica de consumo como principal mola propulsora, apresenta dificuldades em abrir espaços para a expansão de nova cultura produtiva, a partir do modelo de desenvolvimento sustentável. 
A equidade social tão buscada, mas ao mesmo tempo não observada, é de grande importância para o desenvolvimento sustentável. É difícil exigir de uma sociedade consciência ambiental sem que antes ocorra suprimento das necessidades do individuo. Apregoar noções ou definições de sustentabilidade em países com infra-estrutura adequada, educação de qualidade, saúde e emprego torna-se mais fácil, visto que suas necessidades básicas já estão sendo supridas. O mesmo é visto de outra forma quando se olha um país sem essas características, colocando em outra dimensão a discussão sobre desenvolvimento sustentável, frente mesmo a prioridade de auto-preservação do individuo.

\footnotetext{
A compreensão adequada da crise pressupõe, portanto, que esta diz respeito ao esgotamento de um estilo de desenvolvimento ecologicamente depredador, socialmente perverso, politicamente injusto, culturalmente alienado e eticamente repulsivo. (GUIMARAES, 2001, p.20).
}

Guimarães (2001) sugere-nos que é preciso reconhecer que as conseqüências ecológicas do modo como a população utiliza os recursos do planeta estão associados ao padrão de relações entre os próprios seres humanos. É de fato insensato desvincular os problemas do meio ambiente dos problemas do desenvolvimento, já que os primeiros são simples expressões das falências de um determinado estilo de desenvolvimento.

Passaram-se quase vinte anos da Conferência de Estocolmo para que fosse gerado um documento que concretizasse uma política global para o desenvolvimento sustentável, a Agenda 21, fruto da Conferência das Nações Unidas sobre o Meio Ambiente e Desenvolvimento, realizada em 1992, no Rio de Janeiro (Rio 92): "Como o próprio nome sugere, a Agenda 21 é um programa recomendado para governos, agências de desenvolvimento, organizações das Nações Unidas e grupos setoriais independentes colocarem em prática, a partir da data de sua aprovação, 14 de junho de 1992, e ao longo do século 21, em todas as áreas onde a atividade humana incide de forma prejudicial ao meio ambiente." (CONFERÊNCIA DAS NAÇÕES UNIDAS SOBRE MEIO AMBIENTE E DESENVOLVIMENTO, 1997, p. 9 apud OLIVEIRA, 2000).

No capítulo 14 da Agenda 21, são apresentadas as recomendações para o desenvolvimento rural e agrícola sustentável. As diretrizes gerais do "Nosso Futuro Comum" são retomadas: "o principal objetivo do desenvolvimento rural e agrícola sustentável é 
aumentar a produção de alimentos de forma sustentável e incrementar a segurança alimentar", e, para tanto, seria necessário promover ações na área de educação, fazer uso de incentivos econômicos e desenvolver tecnologias novas e apropriadas. Os resultados almejados seriam: "uma oferta estável de alimentos nutricionalmente adequados, o acesso a essas ofertas por parte de grupos vulneráveis, paralelamente à produção para os mercados; emprego e geração de renda para reduzir a pobreza; e o manejo dos recursos naturais juntamente com a proteção do meio ambiente." E, os principais instrumentos de política seriam a reforma da política agrícola, a reforma agrária, a participação, a diversificação dos rendimentos, a conservação da terra e um melhor manejo dos insumos (CONFERÊNCIA DAS NAÇÕES UNIDAS SOBRE MEIO AMBIENTE E DESENVOLVIMENTO, 1997, p. 151 apud OLIVEIRA, 2000).

De acordo com Denardi et al. (2000), o termo desenvolvimento sustentável possui longa história de construção. Segundo este autor, entre a Segunda Grande Guerra Mundial e meados da década de sessenta, não havia distinção entre desenvolvimento e crescimento econômico. No entanto, as condições de vida de muitas populações não respondiam a esse crescimento e em alguns casos até pioravam, mesmo quando os seus países haviam alcançado elevadas taxas de crescimento. Estes fatos provocaram "grande insatisfação com essa visão do desenvolvimento como sinônimo de crescimento econômico" (DENARDI et al., 2000). A idéia de desenvolvimento foi paulatinamente incorporando uma série de aspectos sociais: emprego, necessidades básicas, saúde, educação, longevidade.

Segundo Altieri (2000), para se compreender os sistemas agrícolas atuais, temos que conhecer sua sustentabilidade, pois a agricultura é afetada pela evolução dos sistemas socioeconômicos e naturais.

De acordo com Bicalho (1998) os três indicadores descritos na figura 1 devem ser atendidos pela operacionalização do desenvolvimento rural sustentável alcançando o objetivo máximo, a geração e o suporte de modos de vida sustentáveis. O autor continua em seus ensinamentos que a capacidade está relacionada às funções básicas das pessoas como nutrição adequada, vestimentas confortáveis e boa qualidade de vida. Esta qualidade de vida é entendida como a capacidade do grupo escolher e avaliar suas ações. A eqüidade refere-se à distribuição menos desigual dos bens, habilidades e oportunidades. Inclui também o fim da discriminação às mulheres e às minorias, além do fim da miséria rural ou urbana. E finalmente 
a sustentabilidade que está ligada à nova visão global acerca da poluição, desmatamento, alta exploração de recursos não-renováveis, além da degradação ambiental

Segundo Verona (2008) os indicadores exercem uma função fundamental na geração de dados para a avaliação de sustentabilidade, indicando a direção, a prioridade das mudanças e direcionando um caminho de proposta para contribuir com um desenvolvimento sustentável baseados nos agroecossistemas. Sendo assim, um estudo com indicadores não apenas proporciona a construção de propostas de agroecossistemas mais adequados, através da transformação de dados em relevantes informações, mas também informações para a construção de estratégias políticas e de planejamento para um desenvolvimento sustentável.

Figura 1 - Fluxograma da operacionalização do desenvolvimento rural sustentável.

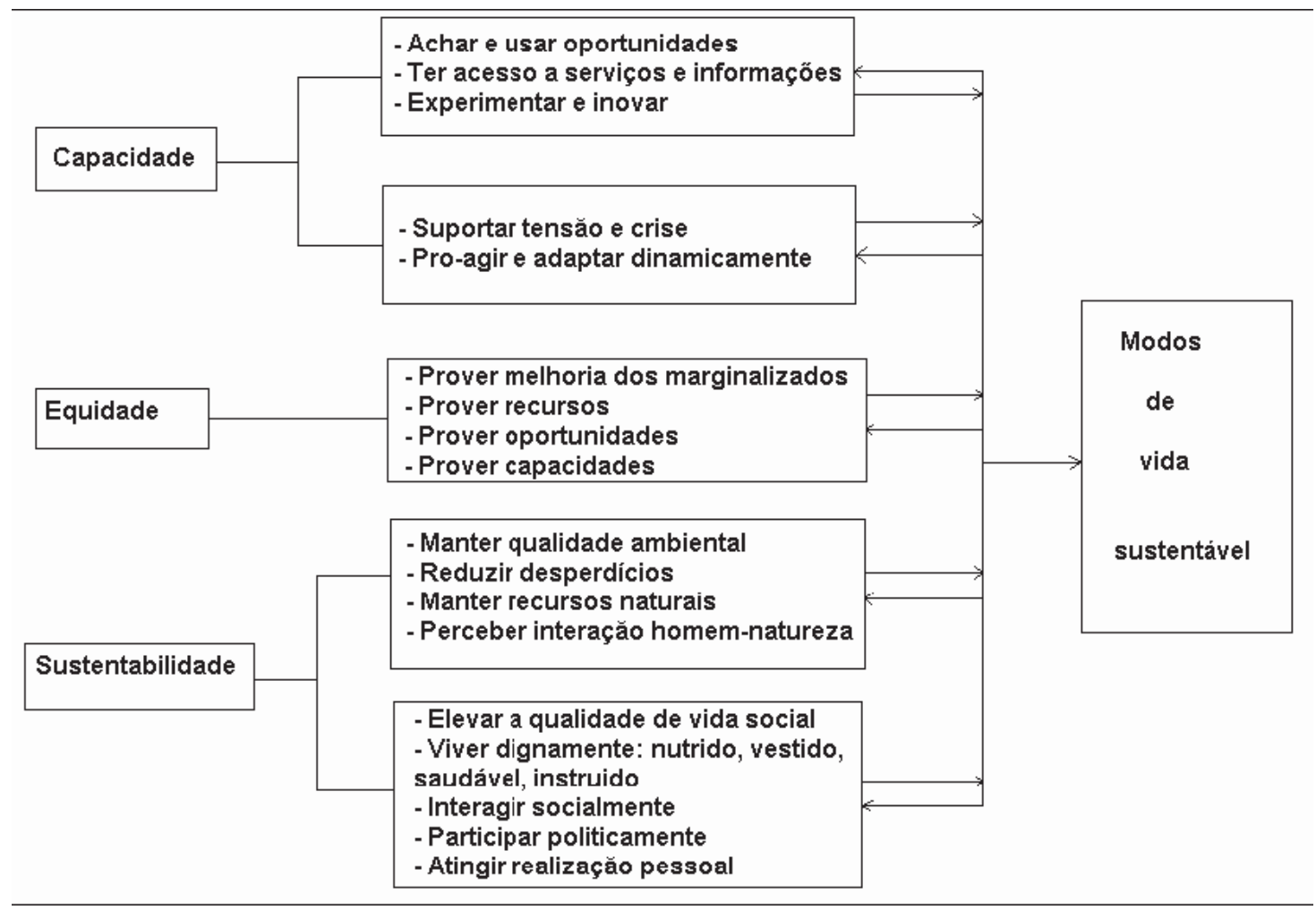

Fonte: BICALHO (1998 pág. 78)

Aprofundando esta teoria e dando origem a estudo de agrupamento de indicadores, Freudenberg (2003 apud VERONA 2008) classifica e define os indicadores como: a) Individuais - como sendo uma forma de menu, com indicadores isolados ou um 
banco de dados estatísticos; b) Temáticos - como indicadores individuais que são agrupados em conjunto considerando suas características acerca de um específico tema ou área. Este modelo de avaliação requer uma identificação de determinados tipos de indicadores que estão ligados ou relacionados de alguma forma específica. Geralmente, esta proposta apresenta os indicadores isoladamente, ao invés de sintetizado em um indicador composto; c) Compostos formados quando os indicadores temáticos são sintetizados em um índice e apresentados como uma média composta simples.

Uma definição quanto ao desenvolvimento sustentável elaborada em conjunto pela UICN, Fundo Mundial para Natureza (WWF) e Programa das Nações Unidas para o Meio ambiente (PNUMA), alude ao processo de melhora das condições de vida das comunidades humanas e, ao mesmo tempo, respeita os limites dos ecossistemas. (SACHS, 1998 apud PIRES, 2002, p. 73 apud LIMA, 2009) apresenta diferentes dimensões da sustentabilidade necessárias ao se planejar o desenvolvimento:

\subsubsection{Dimensão ambiental}

Dentro da dimensão ambiental os indicadores de solos apresentam grande importância na avaliação de sustentabilidade na agricultura. Doran e Parkin (1994 apud VERONA, 2008) sugerem uma definição complexa para qualidade do solo, que envolve a capacidade do solo funcionar dentro dos limites de um ecossistema, sustentando a produtividade biológica, mantendo a qualidade do meio ambiente e promovendo a saúde das plantas e dos animais.

Pode ser incrementada pelo uso de algumas alavancas, como a intensificação do uso dos recursos potenciais com um mínimo de dano aos sistemas de sustentação da vida, limitação do consumo de combustíveis fosseis e de outros produtos esgotáveis ou ambientalmente prejudiciais, redução da carga de poluição, auto-alimentação do consumo material pelos países ricos, intensificação da pesquisa de tecnologias limpas, definição de regras para uma adequada proteção ambiental (SACHS, 1998 apud PIRES, 2002 apud LIMA 2009). 
Corrêa (2007 apud VERONA, 2008) cita o termo "consciência ecológica" caracterizando como um importante critério para avaliar o ponto crítico de incipiente interação homem-natureza, relacionando-o com o atributo da adaptabilidade, que inclui os processos de aprendizagem.

\title{
2.2.2 Dimensão Econômica
}

Necessidade de gestão mais eficiente dos recursos e de um fluxo regular de investimento publico e privado. A eficiência econômica deve ser avaliada por critérios macros sociais e não apenas em termos da lucratividade micro empresarial (SACHS, 1998 apud PIRES, 2002 apud LIMA, 2009).

Os fatores econômicos são indicadores importantes na avaliação de sustentabilidade de agroecossistemas familiares, porém não devem ser usados isoladamente e com critérios financeiros de curto prazo, como por exemplo de análise custo-benefício de um produto agrícola em um determinado momento (MASERA; LÓPEZ-RIADURA, 2000 apud VERONA, 2008) .

\begin{abstract}
Não deve ficar somente na ousadia, nas atitudes e na determinação dos agricultores, a busca de uma agricultura que seja ecologicamente aceitável, economicamente viável, socialmente justa, solidária e adaptável. O desenvolvimento de uma atividade agrícola que recupere, mantenha ou melhore a qualidade dos recursos naturais disponíveis, que produza não só para garantir a reprodução da família, mas que seja capaz de gerar excedentes (....) precisa encontrar forte sustentação na academia.(CASALINHO, 2003, p. 134 apud VERONA, 2008, p. 59).
\end{abstract}

\subsubsection{Dimensão sócio-cultural}

Nessa dimensão social, a capacidade de autogestão, de autodependência dos agroecossistemas, é de grande importância. Trata-se de um atributo da agricultura sustentável, e merece uma análise especial quanto aos seus indicadores. Masera e López-Riadura (2000) apud Verona (2008) reforçam esta afirmativa de que autogestão é um dos atributos fundamentais em um caminho para alcançar uma agricultura sustentável. A quantificação das relações de um sistema com o meio exterior colabora com o entendimento do nível de sustentabilidade deste agroecossistema. Destacam esses autores que quanto maior 
a dependência de insumos externos, maior é a vulnerabilidade do agroecossistema, principalmente por não haver controle quanto aos preços destes insumos.

Os autores trabalham com a consolidação de outro tipo de desenvolvimento, onde se objetiva construir uma “[...] civilização do ser, em que exista maior equidade na distribuição do ter". Traduz-se na busca do eco-desenvolvimento em uma pluralidade de soluções particulares que respeitem as especificidades de cada ecossistema, de cada cultura e de cada local.

\subsection{Agroecologia e tecnologias sustentáveis.}

A seguir são sistematizadas diferentes tecnologias alternativas, situando-as nas escolas de agricultura alternativa sustentável.

A agroecologia é derivada de pelo menos duas ciências, a ecologia e a agronomia. Cada uma delas ocupando-se de suas próprias pesquisas. A ecologia preocupa-se, preferencialmente, em estudar os sistemas naturais e a agronomia dedica-se à prática da agricultura. Conforme Gliessman (2005) a fronteira entre a ciência pura e a natureza, por um lado, e a ciência aplicada e o esforço humano, por outro, manteve as duas disciplinas relativamente separadas, com a agricultura cedida ao domínio da agronomia.

A Agroecologia torna-se a ferramenta pela qual se pode chegar a um desenvolvimento sustentável no meio rural. Para Caporal (2004) a agroecologia é entendida como um enfoque científico destinado a apoiar a transição dos atuais modelos de desenvolvimento rural e de agricultura convencionais para estilos de desenvolvimento rural e de agriculturas sustentáveis.

O objetivo da agroecologia, segundo Gliessmann (2001), é o desenvolvimento de uma agricultura que seja, ao mesmo tempo, ambientalmente sustentável, produtiva e rentável. Através de pesquisas interdisciplinares, em direta interação com os conhecimentos locais e empíricos dos agricultores, podem ser desenvolvidos e aplicados métodos que reduzam a dependência de insumos externos à propriedade e seus efeitos sobre o meio ambiente, permitindo a manutenção sustentável dos agricultores e de suas comunidades. 
A particularidade social da agroecologia reside no fato de estar baseada na ação coletiva de determinados grupos na sociedade civil com referência na sua relação com a natureza.

Primeiramente, ela não ignora o conhecimento dos agricultores e valoriza, especialmente, a preservação dos recursos naturais, a geração de crescimento econômico sem destruição da natureza, fatores estes que, juntamente com o trabalho, constituem a base histórica da produção agrícola. Além disso, com a agroecologia, o controle sobre o uso de tecnologias e a determinação da intensidade de trabalho a elas associadas permanece com os agricultores.

Mais do que uma disciplina especifica, a Agroecologia se constitui num campo de conhecimento que reúne várias “[...] reflexões teóricas e avanços científicos, oriundos de distintas disciplinas" que tem contribuído para conformar o seu atual corpus teórico e metodológico (GUZMAN CASADO et al., 2000). As elucidações iniciais mostram um direcionamento rumo a um conceito mais amplo da agroecologia como uma ciência multidisciplinar capaz de fazer a ponte entre o insustentável e o sustentável.

\footnotetext{
O enfoque agroecológico pode ser definido como "a aplicação dos princípios e conceitos da Ecologia no manejo e desenho de agroecossistemas sustentáveis", num horizonte temporal, partindo do conhecimento local que, integrando ao conhecimento cientifico, dará lugar a construção e expansão de novos saberes socioambientais, alimentando assim, permanentemente, o processo de transição agroecológica. (GLIESSMAN, 2000, p. 35).
}

Uma vez mais é observada a importância de novos saberes, para isso há uma palavra que se torna central para a agroecologia: transição. A transição é manifestada na implementação de mudanças. Essa idéia de mudança se refere a um processo de evolução contínua e crescente no tempo, porém, sem ter um momento final determinado.

\footnotetext{
Entretanto, por se tratar de um processo social, isto é, por depender da intervenção humana, a transição agroecológica implica não somente na busca de uma maior racionalização econômico-produtiva, com base nas especificidades biofísicas de cada agroecossistema, mas também numa mudança nas atitudes e valores dos atores sociais em relação ao manejo e conservação dos recursos naturais. (CAPORAL, 2004, p. 12).
}

Ressalta-se que a Agroecologia não é uma solução final para o desenvolvimento rural. Mas busca nos conhecimentos e experiências, um método de 
intervenção que, mantenha coerência com suas bases epistemológicas contribuindo na formação e transformação do comportamento rural em um comportamento sustentável.

A história da agroecologia passa por todo desenvolvimento do homem e sua relação com o meio ambiente, seu aprendizado e suas descobertas de novas tecnologias. Na Europa, como afirma Altieri (2002), a agricultura era intimamente ligada à cultura e os padrões culturais definiam diretamente a forma de cultivo e manejo das plantações. A colonização das Américas, também nos transmite uma visão real de como a agricultura regrediu na sua relação com o meio e na forma que se manejava a produção.

Este processo junto com as doenças, a escravidão e a freqüente reestruturação da base agrícola das comunidades rurais para fins coloniais e de mercado, contribuía para a destruição e abandono das tecnologias sustentáveis como os sistemas de irrigação e especialmente o empobrecimento de tecnologias racionais (alternância no cultivo, controle biológico e manejo de solos) da agricultura local, que dependia muito da transmissão de forma cultural. (HECHT, 1999, p. 19).

Na década de 1980 à agroecologia foi conferida a condição de ser uma metodologia e uma estrutura de conceitos que seriam referências para o estudo de agroecossistemas. Novos conceitos começaram a surgir e a serem trabalhados no meio científico e entre eles pode-se destacar o de sustentabilidade, que conforme Gliessman seria:

[...] no sentido mais amplo, a sustentabilidade é uma versão do conceito de produção sustentável - a condição de ser capaz de perpetuamente colher biomassa de um sistema, porque sua capacidade de se renovar ou ser renovado não seja comprometida. (GLIESSMAN, 2005, p. 52).

Decisivo para os agricultores, entretanto, são os possíveis benefícios à qualidade de vida, especialmente no que se refere à saúde e à maior facilidade no trabalho. Ambos os elementos, envolvidos no uso de tecnologias ecológicas, estão no centro do debate sobre inovações tecnológicas na agricultura, pois estão diretamente associados às necessidades dos seres humanos que trabalham na agricultura e, portanto, podem servir de ponto de partida para a formação da consciência política dos agricultores.

A possibilidade de reduzir e facilitar o trabalho, assim como torná-lo mais saudável, através de uma melhor relação com a natureza é especialmente importante nas decisões dos agricultores sobre inovações tecnológicas. (ANDRIOLI, 2008). 
Porém, se trata também de um processo de aprendizagem, na medida em que os agricultores são capacitados a refletir organizadamente sobre seus problemas concretos e, acompanhados de conhecimentos científicos, a desenvolver soluções que, tendo em vista a sua complexidade, exigem uma ampla organização social e política, de forma que o capital cultural (conhecimento) possa se converter em capital social. (BOURDIEU, 1983 apud ANDRIOLI, 2008).

A agricultura familiar vive um momento de resgate da sua importância econômica e social no Brasil. Conforme Wanderley (2000):

[...] de vistos como os 'pobres do campo' e produtores de baixa renda os pequenos agricultores começaram a serem percebidos como agentes que vão trazer uma nova concepção de agricultura, diferente da que é dominante em termos produtivos, caracterizada por grandes propriedades e, também, centrada nas mãos de uma minoria. (WANDERLEY, 2000, p. 29).

A agroecologia veio para ser uma alternativa de um processo de produção agrícola que não contemplava a todos os produtores agrícolas, em especial os produtores familiares. Ela possibilita integrar os princípios agronômicos, ecológicos e socioeconômicos às atividades agrícolas.

Altieri e Yurjevic (1991) ressaltam a importância do conhecimento que o produtor já detém: "O conhecimento local dos agricultores sobre o ambiente, plantas, solos e processos ecológicos possui uma grande importância nesse novo paradigma agroecológico.”

O processo de restaurar a saúde ecológica de uma ou várias propriedades rurais não é o seu único objetivo. Também objetiva a sustentabilidade que não se torna possível sem a preservação da diversidade cultural constante nos agricultores locais. $\mathrm{O}$ conhecimento do agricultor, normalmente a ele passado pelas gerações anteriores, vai lhe possibilitar desenvolver práticas agrícolas e emprego de tecnologias de baixo uso de insumos que se aliam ao que a agroecologia preconiza como diversidade de cultivos, otimização dos espaços, reciclagem de nutrientes, conservação da água e controle de pragas e doenças.

O desafio agroecológico, no entanto, está em mudar ou alterar culturalmente paradigmas preexistentes e também lutar contra uma corrente muito forte de produtores de grandes monoculturas. A agricultura familiar tem como característica a produção variada e de subsistência para garantir essa forma de vida, é extremamente vital que 
se mostrem variáveis no manejo onde se maximize a produção, gerando, de certa forma, o necessário para o sustento e o desenvolvimento do produtor rural.

Presentemente, a agroecologia tem seu campo de influência que perpassa os limites meramente de atividade alternativa a um modelo de agricultura vigente e vai conter outras perspectivas de análise que não são somente ambientais, tais como a econômica, social e cultural. Fatores que dela podem resultar passam a ser objeto de pesquisas e estudos e entre eles pode-se destacar a valorização do agricultor, a sua inserção na sociedade de uma forma mais efetiva, a relação do produtor agroecológico com o consumidor de seus produtos, relação do produtor com o mercado e possíveis novas técnicas de comercialização que podem ser agregadas. Gliessman completa esta nova perspectiva da agroecologia ao dizer que:

[...] a agroecologia [...] é um agente para as mudanças sociais e ecológicas complexas que tenham necessidade de ocorrer no futuro a fim de levar a agricultura para uma base verdadeiramente sustentável. (GLIESSMAN, 2005, p. 56).

Na década de 1980 surgem discussões, críticas e são propostas ações ao padrão agrícola dominante de desenvolvimento agrário visando, principalmente, a preservação do pequeno produtor agrícola familiar e de suas atividades. Conforme PTA/FASE apud Almeida:

\footnotetext{
Os novos projetos que surgem, as novas experiências de produção e de vida, mesmo que por vezes ambíguas, são chamadas pela vontade geral de responder aos "interesses do pequeno agricultor" a fim de reforçar sua capacidade de resistência na terra, consolidar sua organização, seu poder de enfrentamento frente às forças econômicas e políticas adversas, seu nível de vida e sua segurança financeira. (PTA/FASE, (1986) apud ALMEIDA (1999, p. 57-58). Os pontos principais dessa visão residem na "tecnologia" - como instrumento material da atividade produtiva e da comercialização - e nas "formas de organização social". (ALMEIDA, 1999, p. 58).
}

Fazia-se necessário que dada as condições para que o agricultor familiar não permanecesse à margem do processo produtivo, não se extinguisse e que fosse resgatada a sua importância econômica e social. Os fundamentos desta nova forma de ver a agricultura familiar estavam na adoção de tecnologias, como instrumentos materiais da atividade produtiva e da comercialização dos produtos, e nas formas de organização social a serem adotadas. 
O ideário agroecológico vai se estabelecer carregado de novas propostas para a agricultura visando torná-la viável nas dimensões biológica, técnica, econômica, política e social. O resultado final seria um agricultor com autonomia, solidário com as demais pessoas e com relações de respeito à natureza. A questão econômica da atividade não passou despercebida como coloca Almeida:

Os atores que se colocam como defensores da agroecologia reconhecem, entretanto, que, no curto prazo, essa proposição poderá se impuser não pelos seus ideais ecológicos, mas pela sua "funcionalidade econômico-social. (ALMEIDA, 1999).

A utilização de adubos orgânicos e a adoção da rotação de culturas são exemplos de atividades agrícolas baseadas na elevação da matéria orgânica, reciclagem de nutrientes, eliminação de substâncias químicas solúveis e controle biológico de pragas e doenças. Pesquisas de Altieri, comparando tecnologias convencionas com métodos de produção ecológica, demonstram que, pela não utilização de insumos externos como adubos químicos e agrotóxicos, os custos de produção na agricultura ecológica são 22,4\% menores aos da agricultura convencional. (ALTIERI, 2001).

Os efeitos da tecnologia ecológica sobre o meio ambiente também podem ser considerados mais sustentáveis, tendo em vista que foi constatada uma menor perda de solo e água, uma melhor estrutura, um maior equilíbrio de nutrientes e uma maior atividade de microorganismos no solo. Todos estes fatores também assumem uma dimensão econômica, considerando a relação existente entre a produtividade e a conservação da qualidade dos recursos naturais existentes.

A agroecologia vai trabalhar principalmente com a agricultura familiar por ser esta, conforme Carvalho, Fani e Ferreira (2005) a forma de organização da produção mais próxima dos preceitos da agroecologia e, portanto, da sustentabilidade. Este entendimento é reforçado por Assis e Romero (apud Pinheiro):

De modo geral, são os sistemas familiares de produção que estão mais bem posicionados para implementar estas novas práticas agroecológicas, na medida em que estes possuem estruturas de produção diversificadas, a um nível desejado, passíveis de supervisão e controle do processo de trabalho. (ASSIS; ROMERO, 2002, p.77 apud PINHEIRO, 2004, p. 83). 
Apesar da hegemonia das assim chamadas tecnologias modernas na agricultura, métodos agrícolas tradicionais ainda podem ser encontrados. A combinação entre tecnologias tradicionais e "modernas", que foi desenvolvida em decorrência do reduzido poder de investimento dos agricultores, pode ser uma explicação para o fato da agricultura familiar ter um menor custo de produção e para a existência de muitas pequenas propriedades agrícolas.

No entanto, a grande novidade em termos de resistência a tecnologias geradoras de dependência, exclusão social e destruição ambiental é o movimento agroecológico. A agroecologia pode ser entendida com uma reação às conseqüências negativas da aplicação das assim chamadas teorias modernizadoras, especialmente nos países mais pobres. Ela tem, por isso, um forte componente social, pois, pela sua capacidade de redução de insumos externos e de preservação das condições naturais de produção, ela pode atuar de uma forma economicamente estabilizadora para pequenos agricultores, com intuito de redução da dependência tecnológica (WOLFF, 1992 apud ANDRIOLI, 2008). Porém, ela somente pode adquirir uma maior importância social como inovação técnica na medida em que não se limita à correção de erros da tecnologia agrícola tradicional. Potencialmente, portanto, ela pode almejar, através de uma ação interdisciplinar, a ruptura com o desenvolvimento tecnológico dominante no meio rural, contribuindo para a construção de possibilidades de organização alternativa dos pequenos agricultores, que venham a fortalecer sua autonomia de ação.

A agricultura ecológica é mais intensiva em trabalho que a agricultura convencional no período de transição, o que também varia de cultura para cultura. $\mathrm{Na}$ agricultura ecológica o agricultor pode ser melhor remunerado se a proporção dos custos de produção com insumos externos for agregada em proveito do trabalho humano. Na economia capitalista, onde, tendencialmente, aumenta a introdução de instrumentos de produção que poupam trabalho e reduz a parcela de valor destinada ao trabalho, à perspectiva anteriormente descrita pode ser uma alternativa de resistência, se ao invés de mais capital constante é investido capital variável (trabalho especializado) e conhecimento na atividade agrícola.

Considerando a existência de uma dualidade da agricultura familiar, ou seja, a interação entre produção e consumo, pode ser constatada uma crescente atenção dos agricultores com relação à qualidade dos alimentos e suas conseqüências à saúde da família 
(ANDRIOLI, 2008). Essa relação entre produção de valor e necessidades humanas, contraditória com o modo de produção capitalista, constitui uma particularidade importante da agricultura familiar com relação ao uso de tecnologias.

O debate sobre inovações tecnológicas na agricultura pode adquirir uma dimensão política, ao unificar agricultores atingidos por tecnologias de caráter destrutivo, servindo como ponto de partida para a construção de um processo gerador de consciência crítica. A possibilidade de desmascarar o caráter explorador e destruidor da agricultura capitalista através da experiência com a agroecologia e de associar a necessidade da sua organização política com outras forças anticapitalistas na sociedade, pode conferir uma dimensão revolucionária a um movimento ecológico e cooperativo dos agricultores familiares. Isso, entretanto, depende da possibilidade de desvelamento das contradições da economia capitalista, partindo de uma experiência de produção socializadora do seu interior, de maneira que as estruturas de dependência tecnológica, econômica e social deixem de ser ocultas e passem a ser conscientes, conduzindo à formação de movimentos sociais mais amplos. Considerando a relação potencial da agroecologia com as necessidades concretas dos seres humanos atingidos pela tecnologia agrícola, essa possibilidade parece existir, confirmando as experiências progressistas de agricultores com as "tecnologias socialmente apropriadas".

A agricultura biodinâmica surgiu na Alemanha, com Rudolf Steiner (1924). Apresenta como tecnologias o uso de preparados biodinâmicos, que são organismos vivos, feitos à base de extratos de plantas e de soluções orgânicas e minerais. Estes podem ser divididos em dois grupos: os que são pulverizados no solo e nas plantas, e os que são inoculados em composto ou outras formas de adubos orgânicos como biofertilizantes e chorumes.

Filosoficamente, a agricultura biodinâmica estrutura-se em função de "novas idéias fundamentais sobre as relações entre a terra, o solo e as forças formativas do etérico, astral e da atividade do ego na natureza". Em termos organizativos, a biodinâmica funciona à base de cooperativas e associações de agricultores em fazendas experimentais. A aplicabilidade do conceito foi testada diversas vezes, ao longo deste século, sendo a experiência talvez mais significativa a ocorrida no segundo pós-guerra nas fazendas coletivas da então Alemanha Oriental. (JESUS, 1985). 
Agricultura orgânica (biológica) surgiu pelo botânico agrônomo inglês Albert Howard e suas experiências na Índia, entre 1920-40, com ênfase na compostagem e na vida microbiana. Segundo Paschoal (1994), os princípios e técnicas orgânicos são: manejo e conservação do solo e da água com o controle de erosão, adubações orgânicas, rotação de culturas, incorporação de matéria orgânica e de nutrientes minerais, cultivo múltiplo, manejo natural de pragas, patógenos e ervas invasoras, uso adequado de máquinas e implementos agrícolas, uso de fontes alternativas de energia e integração agricultura - criação animal. Howard sustentava que a verdadeira fertilidade dos solos deveria estar assentada sobre um amplo suprimento de matéria orgânica e principalmente na manutenção de elevados níveis de humus no solo. (JESUS, 1985).

A chamada agricultura biológica utiliza-se, em parte, de adubação orgânica. Referindo-se à base científica (e técnica) da agricultura biológica, Claude Aubert menciona o tripé formado pela fertilização, a rotação da cultura e o trabalho do solo. Detendose na questão da fertilização, ele esclarece que havia a mania de dizer que a agricultura biológica era, simplesmente, abandonar os adubos químicos e usar adubos orgânicos; essa é só uma parte dessa agricultura. A fertilização, em agricultura biológica, não consiste em tirar todo o adubo mineral para se usar apenas o adubo orgânico, a matéria orgânica é à base da fertilização do solo, mas, apesar disso, usam-se também fertilizantes minerais. Fora poucas exceções, a gente usa só minerais naturais que não sofreram transformação química, apenas foram moídos. São, por exemplo, os fosfatos naturais, os basaltos, as rochas calcárias e ricas também em magnésio. Estas rochas têm a vantagem, sobre os adubos químicos, de serem muito mais equilibradas, especialmente por conterem mais oligoelementos. (AUBERT, 1985).

A agricultura natural surgiu no Japão, pela Igreja Messiânica (193040). Recentemente, a agricultura natural tem se concentrado na utilização de microorganismos benéficos. Considerando o autor Seó (1984), como representante da escola Natural, pode-se citar algumas de suas tecnologias alternativas: compostagem, adubação verde, controle natural de pragas, biodigestor, uso de plantas consorciadas, uso de inseticidas naturais e armadilhas que não utilizam venenos como a armadilha luminosa, as garrafas armadilhas, dentre outras técnicas como a utilização de casas para atrair pássaros e morcegos, reciclagem de materiais 
como o papel para se fazer mudas, caçadeiras de larvas de mosca e a utilização da energia solar através dos secadores, fornos, aquecedores e destiladores solares.

Agricultura Agrobiológica surgiu na França, com Claude Aubert, na década de 1960. Algumas técnicas da agricultura agrobiológica são: fertilização orgânica, rotação de culturas e o trabalho do solo. A fertilização é feita através da compostagem de matéria orgânica que visa nutrir os organismos vivos do solo e devem ser utilizadas de acordo com as condições da propriedade. Pelo princípio da Trofobiose acredita-se que plantas bem nutridas não ficam doentes. Utilizam também a adubação verde e os fertilizantes minerais, porém estes não sofrem transformações químicas, são apenas moídos. São Rochas moídas.

Agricultura ecológica surgiu nos EUA e na América Latina com Miguel Altieri, José Lutzemberger, Ana Maria Primavesi, Stephen Gliessman, dentre outros, a partir dos anos 1970. Como já definido em tópico acima, o desafio da escola agroecológica é alcançar agroecossistemas sustentáveis, que se assemelhem aos ecossistemas naturais mantendo uma produção razoável. Para tal o agricultor deve usar o conceito de ecossistema no desenho e manejo do agroecossistema, ou seja, deve esforçar-se para manter os ciclos de nutrientes tão fechados quanto possível, a fim de reduzir as perdas de nutrientes do sistema. Nesse sentido, Gliessman (2005) aponta algumas técnicas como a aplicação dos estudos dos fatores macro-ambientais em relação aos cultivos, como a análise do ambiente luminoso, do micro clima, da pluviosidade, do vento, do manejo do solo, da água e do fogo, percebendo no conjunto a interação entre os diversos fatores. Em suma, busca-se a interação ambiental, social e a diversificação.

A permacultura surgiu na Austrália com Bill Mollison, nos anos 1970. De acordo com o Instituto de Permacultura e Ecovilas da Mata Atlântica - IPEMA, a Permacultura trata as plantas, animais, construções, infraestruturas (água, energia, comunicações) não apenas como elementos isolados, mas como sendo todos parte de um grande sistema intrinsecamente relacionado, ou seja, é o sistema agrosilvipastoril no seu conjunto. Portanto, é uma tecnologia alternativa com as características de tratamento dos solos sem arar ou revolver; não utilização de fertilizantes químicos ou compostos, deixando que as plantas e os animais (microorganismos) trabalhem livremente sobre o solo; não gradeamento 
nem uso de herbicidas ou agrotóxicos, pois as pragas e as doenças possuiriam controles naturais. (JESUS, 1985).

Operando com diferentes tecnologias alternativas foi desenvolvido o que foi denominada Produção Agroecológica Integrada e Sustentável - PAIS. Tal tecnologia inspirou-se na atuação de pequenos produtores que optaram por fazer uma agricultura sustentável, sem uso de produtos tóxicos e com a preocupação de preservar o meio ambiente. Integrando técnicas simples e já conhecidas por muitas comunidades rurais, tem como objetivo transformar a agricultura familiar em um negócio sustentável por meio da produção orgânica, mercado de alimentos cada vez mais consumidos no Brasil e no mundo. (BRASIL, 2011).

Criado em 2004 criada pelo agrônomo senegalês Ali N'Diaye, o projeto PAIS se baseia em canteiros circulares com um galinheiro central. Em uma mesma unidade, os agricultores podem cultivar diversos tipos de hortaliças, legumes, carnes, ovos e frutas. O modelo estimula o desenvolvimento sustentável e o uso da agricultura orgânica por meio de um processo produtivo sem uso de agrotóxicos, trabalhando o reflorestamento e, conseqüentemente, preservando o meio ambiente.

Foi criada uma cartilha no ano de 2008 com passo-a-passo para orientar o pequeno agricultor quanto à adoção desta técnica em seu meio de produção. Cujo nome é "PAIS Produção Agroecológica Integrada Sustentável. Mais alimento, trabalho e renda no campo. Saiba como produzir alimentos saudáveis e preservar o meio ambiente”. A qual consta disponível para download gratuito pelo site no Ministério de Integração Nacional.

A cartilha destaca que para alcançar bons resultados, as regras são bastante claras: respeitar o meio ambiente, a vida, os hábitos e os costumes da população e garantir, principalmente, a sustentabilidade das comunidades com menor poder de consumo. Isso se faz com o emprego de técnicas simples já conhecidas por vários produtores rurais. O modelo convida os agricultores familiares ao desenvolvimento sustentável, buscando:

- Estimular a agricultura orgânica por meio de processo produtivo sem o uso de agrotóxicos;

- Reduzir a dependência de insumos vindos de fora da propriedade;

- Apoiar o correto manejo dos recursos naturais; 
- Incentivar a diversificação da produção;

- Evitar o desperdício de alimento, água, energia e tempo do produtor.

Trata-se de uma nova alternativa de trabalho e renda para a agricultura familiar. Possibilita o cultivo de alimentos saudáveis. Tanto para o consumo próprio quanto para a comercialização.

É agroecológica porque dispensa o uso de ações danosas ao meio ambiente, como o emprego de agrotóxicos (adubo e veneno), queimadas e desmatamentos.

É integrada porque alia a criação de animais com a produção vegetal e ainda utiliza insumos da propriedade em todo o processo produtivo.

É sustentável porque preserva a qualidade do solo e das fontes de água, incentiva o associativismo dos produtores e aponta novos canais de comercialização dos produtos, permitindo boas colheitas atuais e futuras.

Ali N'Diaye descreve em artigo publicado pela revista Sebrae que esse método traz benefícios aos agricultores que a implantam. Ao produzir orgânicos, o produtor se insere em um mercado que cresce $20 \%$ ao ano no país. Os alimentos, cultivados sem agrotóxicos, são mais saudáveis e garantem melhoria na alimentação da família. O excedente da produção possibilita um aumento na renda e, conseqüentemente, na qualidade de vida. Além disso, a produção sustentável fixa o pequeno produtor no campo e ajuda a reduzir o êxodo rural. (SEBRAE AGRONEGÓCIOS, 2008).

Nas propriedades que adotam a Pais, as hortas são feitas em sistema de anéis, cada um deles destinado a um tipo de cultura, que complementa a que vem na seqüência. A estrutura circular facilita o deslocamento entre os canteiros. As sementes utilizadas no plantio são produzidas pelos próprios agricultores. A policultura é empregada para garantir alimentação variada para as famílias e para aumentar a competitividade no mercado de alimentos orgânicos. "Se um produto está em baixa, compensa-se com outro, o que não é possível na monocultura”, observa N'Diaye. (SEBRAE AGRONEGÓCIOS, 2008).

No centro do círculo formado pelas hortas fica o galinheiro. O esterco produzido pelas aves é utilizado para adubar as plantas. Além disso, a carne e os ovos contribuem na alimentação da família. Escolheu-se as galinhas pela qualidade do dejeto como fertilizante e pelo custo-benefício. A reciclagem de nutrientes possibilitados pela interação 
animal e vegetal garante uma considerável redução de custos no processo de produção. Um dos segredos para a racionalização dos recursos é o processo de irrigação, que evita o desperdício de água. O sistema é construído com mangueiras, que despejam água por gotejamento apenas em cima das plantas. "Hoje, $70 \%$ da água doce do mundo é usada na irrigação, e grande parte disso é perdido devido ao uso de sistemas inadequados", informa N’Diaye. Com o sistema de gotejamento, além da economia de água, traz ainda outra vantagem para o produtor orgânico. A irrigação por aspersão costuma furar folhas, o que atrai fungos e bactérias. Além disso, lava a terra, levando embora nutrientes importantes. O sistema de gotejamento utilizado na PAIS, além de barato, não traz esses problemas mencionados. (SEBRAE AGRONEGÓCIOS, 2008).

As propriedades também contam com um quintal ecológico, onde é preservada a flora nativa e são plantadas árvores frutíferas e espécies que não precisam de irrigação constante, como abóbora. O objetivo é preservar o meio ambiente e gerar mais alternativas de alimentação saudáveis para os agricultores. Os alimentos produzidos pelos agricultores que utilizam a Pais são vendidos principalmente para quitandas, supermercados e restaurantes. Os produtores também comercializam diretamente em feiras de orgânicos. Outro mercado importante são as prefeituras e governos estaduais, que compram os alimentos para usarem na merenda escolar. (SEBRAE AGRONEGÓCIOS, 2008).

A utilização da tecnologia social por meio da PAIS se propõe como um sistema simples e barato de relacionar agricultura familiar e sustentabilidade. 


\section{REFERENCIAL DE ANÁLISE}

Este capítulo tem por objetivo sistematizar os conceitos que serviram como referência para o presente estudo e análise da relação da lógica da agricultura familiar com os mesmos.

\subsection{Agricultura convencional e agricultura alternativa}

Segundo Souza (2005) o conceito de "agricultura convencional" usado no período da "Revolução Verde" é um modo agrícola onde prevalece à busca da maior produtividade através da utilização intensa de insumos externos, o que em curto prazo traz resultados econômicos visíveis como o aumento da produtividade e eficiência agrícola. No primeiro momento também o aumento da produtividade contribui para a diminuição da migração rural e melhora a distribuição de renda, porém em longo prazo trazem danos ambientais que não são contabilizados pelos adeptos da agricultura convencional, como também são inseridos aparatos tecnológicos que substituem progressivamente a mão-de-obra empregada.

Reinjntjes, Haverkort e Waters-Bayer (1994) explicam que o modo de exploração da "agricultura convencional" é intensiva em capital, consome recursos nãorenováveis é em sua maioria voltada ao mercado externo. Verifica-se que pelo intensivo uso 
de capital que este tipo de agricultura necessita de dinheiro para tal investimento, bem como ao adotar estes insumos externos fica mais dependente de atores externos (no caso fornecedores).

O fato de que esta dependência de insumos externos acarreta em prejuízos, pois para aumentar a produtividade há a necessidade do uso excessivo de fertilizantes químicos e combustível, o que em um primeiro momento causa uma superprodução, só que posteriormente ocorrem aumentos desses insumos ocasionando diminuição do preço auferido na produção agrícola, devido sua dependência, e tendo superprodução no mercado (muita oferta) não pode repassar o aumento para os consumidores. Também outro fato é o quanto ao uso intensivo de agroquímicos resultando em contaminação dos lençóis freáticos, rios e empobrecimento do solo, acarretando em prejuízos para a sociedade. (SANCHS apud REINJNTJES, HAVERKORT e WATERS-BAYER, 1994).

$\mathrm{Na}$ "agricultura convencional" observa-se uma lógica de que exploração ao máximo da natureza e que ela está presente para nos servir, sem observar o limites de sua utilização, o que foge ao conceito de sustentabilidade. Também verifica-se que o plantio é focado na monocultura desenvolvida em larga escala, o que a longo prazo pode gerar um estreitamento da diversidade genética do meio ambiente explorado.

Diante deste contexto, pode-se dizer que agricultura convencional se adequa mais a agricultura patronal a qual dispõe de maiores recursos, e a agricultura familiar à alternativa.

Na figura 2 aponta-se as principais diferenças entre a agricultura convencional à ecológica (alternativa) de modo a se ter uma visão mais precisa quanto ambas opções.

Figura 2 - Quadro Agricultura Convencional x Agricultura Ecológica.

\begin{tabular}{|c|c|}
\hline Agricultura Convencional & Agricultura Ecológica \\
\hline \begin{tabular}{l}
\multicolumn{1}{c}{ Exploração } \\
- $\quad$ Custo das externalidades freqüentemente não \\
contabilizadas; \\
- Benefícios de curto prazo sobrevalorizado com \\
relação às conseqüências de longo prazo; \\
- Baseia-se em uso bastante intenso de recursos não- \\
- $\quad$ Elenováveis;
\end{tabular} & $\begin{array}{l}\text { Conservação } \\
\text { - } \quad \text { Custo das externalidades devem ser considerados; } \\
\text { - Resultados de curto e longo prazo devem ser } \\
\text { igualmente considerados; } \\
\text { - Baseia-se nos recursos renováveis e os recursos } \\
\text { não-renováveis são conservados; } \\
\text { - Consumo reduzido para beneficiar futuras } \\
\text { gerações; }\end{array}$ \\
\hline
\end{tabular}




\begin{tabular}{|c|c|}
\hline $\begin{array}{l}\text { por consumo, mantendo o feito } \\
\text { o crescimento econômico; }\end{array}$ & \\
\hline \begin{tabular}{l}
\multicolumn{1}{c}{ Especialização } \\
- $\quad$ Base genética estreita; \\
- Maior parte dos cultivos em monocultura; \\
- Monocultivo contínuo; \\
- Sistamento de culturas e animais; \\
- $\quad$ Ciência e tecnologia especializada e reducionista;
\end{tabular} & $\begin{array}{l}\text { Diversidade } \\
\text { - Ampla base genética } \\
\text { - Mais plantas cultivadas em policultivo; } \\
\text { - Várias culturas em rotação complementar; } \\
\text { - Integração de culturas e animais; } \\
\text { - Sistemas de produção localmente adaptadas; } \\
\text { - Ciência e tecnologia interdisciplinares e } \\
\text { orientadas para os sistemas; }\end{array}$ \\
\hline $\begin{array}{l}\text { Dominação da Natureza } \\
\text { - Natureza consiste primeiramente em recursos a } \\
\text { serem explorados e dominados a pelo homem; } \\
\text { - Alimentos altamente processados, adicionados de } \\
\text { nutrientes }\end{array}$ & \begin{tabular}{l}
\multicolumn{1}{c}{ Harmonia com a Natureza } \\
- \\
Natureza deve ser utilizada respeitando seus \\
limites; \\
- Imitação dos ecossistemas naturais (ex.: agro \\
- floresta); \\
- Alimentos minimamente processados, e \\
naturalmente nutritivos
\end{tabular} \\
\hline $\begin{array}{l}\text { Competição } \\
\text { - Falta de cooperação, interesses pessoais; } \\
\text { - Tradições e cultura rural abandonada; } \\
\text { - Agropecuária é apenas negócio; } \\
\text { - Ênfase a velocidade, a quantidade e ao lucro. }\end{array}$ & $\begin{array}{l}\text { Comunidade } \\
\text { - Maior cooperação, preservação das tradições, } \\
\text { - } \begin{array}{l}\multicolumn{1}{c}{\text { Paberes e cultura rural; }} \\
\text { agricultura; }\end{array} \\
\text { - Agropecuária deve ser uma forma de vida, assim } \\
\text { como um negócio }\end{array}$ \\
\hline $\begin{array}{l}\text { Dependência } \\
\text { - Unidades de produção e tecnologia de larga escala } \\
\text { - E uso intensivo de capital; } \\
\text { - Elevada dependência em fontes externas de } \\
\text { energia, insumo e crédito; } \\
\text { - Consumismo e dependência no mercado; } \\
\text { - Ênfase dada à ciência, especialistas e experts }\end{array}$ & $\begin{array}{l}\text { Independência } \\
\text { - Unidades de produção e tecnologia de menor } \\
\text { escala e uso reduzido de capital; } \\
\text { - Dependência reduzida de fontes externas de } \\
\text { energia, insumos e crédito; } \\
\text { - Ênfase dada ao conhecimento pessoal, } \\
\text { potencialidade e capacidades locais }\end{array}$ \\
\hline $\begin{array}{l}\text { Centralização } \\
\text { - Produção, processamento e marketing } \\
\text { nacional/internacional; } \\
\text { - Menor número de produtores, controle } \\
\text { concentrado da terra, dos recursos e do capital; }\end{array}$ & $\begin{array}{l}\text { Descentralização } \\
\text { - Produção, processamento e marketing mais } \\
\text { regionalizados/local; } \\
\text { - Maior número de produtores, controle } \\
\text { descentralizado da terra, dos recursos e do capital }\end{array}$ \\
\hline
\end{tabular}

Fonte: BEUS e DUNLAP, 1990.

A agricultura alternativa se propõe a ser alternativa à agricultura convencional, enquanto sistema de agricultura empresarial que vê na exploração agrícola um negócio, uma empreitada que deve ter seus lucros maximizados e suas perdas minimizadas. Chega-se a considerar que existe uma grande interação entre o grande capital nacional e internacional com essa agricultura empresarial. (JESUS, 1985). 
Vale descrever segundo Jesus (1985) que a agricultura convencional foi logrando convencer aos agricultores que somente os adubos químicos poderiam manter uma produtividade elevada no campo. A introdução de métodos modernos de agricultura fez com que praticamente todos os anos os agricultores precisassem adquirir novas variedades desenvolvidas nas estações de pesquisa. A reação a este tipo de agricultura intensiva surge ainda na década de dezenove e vinte.

O movimento de Agricultura Alternativa, antecede a chamada revolução verde. Surge na Alemanha, em 1924, pode-se dizer que defendia uma volta à origem dos tempos, antes da agricultura ter utilizado fertilizantes químicos e agrotóxicos, tanto quanto adubos. O termo agricultura alternativa procurava definir todas as técnicas que não utilizavam os artifícios da indústria química, e corresponde a diversas técnicas presentes nas escolas estudadas anteriormente, segundo Khatounian (2001) sobretudo a orgânica e a biodinâmica.

\subsection{Tecnologias sustentáveis e agricultura familiar}

Segundo Sachs (1996) as tecnologias alternativas correspondem ao que vem sendo denominado de "outra agricultura". O mesmo autor descreve que a "outra agricultura" corresponde a formas de sistemas de produção de alimentos e fibras que visam alcançar alguns determinados objetivos, os quais o autor cita como cinco.

- Primeiro objetivo: consiste em uma incorporação mais ampla de processos naturais, como ciclos de nutrientes, fixação de nitrogênio e relação entre pestes e predadores no processo de produção agrícola.

- Segundo objetivo: reduzir o uso dos insumos externos nas plantações que possuam as maiores probabilidades de causar danos ao meio ambiente ou à saúde dos agricultores e consumidores.

- Terceiro objetivo: a "outra agricultura" caracteriza-se por uma maior utilização produtiva do potencial biológico e genético das espécies vegetais e animais. 
- Quarto objetivo: melhoramento das combinações dos padrões de cultivo com o potencial produtivo e as limitações físicas dos terrenos agrícolas para assegurar a sustentabilidade dos atuais níveis de produção de longo prazo.

- Quinto objetivo: refere-se à produção lucrativa e eficiente com ênfase no melhor manejo das plantações e da conservação de recursos agrícolas, hidráulicos, energéticos e biológicos.

Analisando a prática das tecnologias alternativas, ligadas à "outra agricultura" e à agroecologia, verificamos que a agricultura alternativa possui diversas características que a relacionam com o ideal de sustentabilidade referido pelos autores consultados.

Verifica-se enfoque holístico, ótica sistêmica, interrelações, agroecossistema, diversidade elevada, grande estabilidade, incorporação do "custo ambiental", fertilização orgânica, reciclagem de nutrientes, conservação do solo, rotação de cultivos/criação, policultivos, manejo integrado e biológico de pragas e manejo da biodiversidade para o controle de pragas.

Todos estes aspectos definem as tecnologias agrícolas alternativas como plenamente sustentáveis dos pontos de vista social e ambiental. Uma vez definida conceitualmente como sustentável, é importante verificar com que mecanismos conta a agricultura alternativa para garantir estes padrões de sustentabilidade e quais as características mais notáveis dos grupos sociais agrários que efetivamente praticam a agricultura sustentável.

Uma definição mais precisa e ao mesmo tempo abrangente de agricultura sustentável leva em conta três aspectos: o tecnológico, o ecológico e o sócioeconômico. Ressalta-se como a agricultura baseada em alternativas enquadra-se nestes critérios. (CARMO, 1998).

Os aspectos tecnológicos da agricultura sustentável referem-se à adaptação da agricultura familiar às diferentes condições regionais, aproveitando ao máximo os recursos locais. Um dos requisitos básicos para o desenvolvimento auto-sustentável e humano de um país é o desenvolvimento de suas regiões rurais, sobretudo a melhoria da qualidade de vida dos habitantes. Muitas vezes o subdesenvolvimento das regiões rurais tem como uma das causas a falta de energia elétrica. Basicamente a eletricidade pode atender às 
necessidades básicas (domésticas ou comunitárias, incluindo iluminação, lazer, educação, saúde, água potável e comunicação) e necessidades produtivas (derivadas de operações agroindustriais, incluindo o bombeamento de água para fins de irrigação, processamento de produtos, entre outras). Portanto são estes dois ingredientes: água e energia, fundamentais para o desenvolvimento local sustentável da agricultura familiar. (COSTA, 2006).

Carmo (1998) ao relacionar a prática da agricultura familiar aos padrões de sustentabilidade procura demonstrar as possibilidades de interação entre a lógica familiar de produção e o contexto de sustentabilidade agrícola. Percebe-se que o conhecimento das características da agricultura familiar comporta o estudo da complexidade desse segmento produtivo no desenho claro dos seus contornos, buscando eliminar as ambigüidades existentes. Pesquisas têm procurado avançar nessa questão, abrangendo aspectos conceituais que possam ser remetidos a diversos contextos internacionais. A análise do funcionamento da exploração familiar vem no sentido de apreender sua lógica de produção enquanto um equilíbrio da família e o comportamento econômico circundante.

A mesma autora em relação ao emprego de tecnologias pelos agricultores familiares identifica um consenso entre os analistas da questão, pelo qual as propostas tecnológicas (baseadas nas premissas da agricultura convencional) não estão adaptadas às reais necessidades dos agricultores, onde caberia ao progresso técnico o papel uniformizador das condições produtivas de "todos" os agricultores.

A produção familiar, dadas as suas características de diversificação/integração de atividades vegetais e animais, e por trabalhar em menores escalas, pode representar o lócus ideal ao desenvolvimento de uma agricultura ambientalmente sustentável. É fundamental, porém, que seja alvo de uma política estruturada e implementada para esse fim. Um novo padrão de desenvolvimento definido pela auto-sustentabilidade potencializa a participação da agricultura familiar na oferta agrícola. (CARMO, 1998).

Moreira (1998) por outro lado, questionando o caráter inerentemente sustentável, muitas vezes atribuído à agricultura familiar, adverte que se adicionarmos apenas o novo qualitativo da sustentabilidade à concepção dominante, a questão da agricultura familiar, agora "sustentável”, continuará carregando seus elementos conservadores, ao não se constituir como um questionamento da ordem social. 
A agricultura biológica baseia-se na policultura, em mercados locais e regionais com autonomia tecnológica e poucos desperdícios (por exemplo, energia solar e eólica), utiliza-se de processos naturais para uma longa fertilidade e é estável social, econômica e ecologicamente. (INDRIO, 1980).

O trabalho na produção familiar é seu "meio de vida" e a terra é também para produção própria de alimento onde "o produtor e sua família tiram seu sustento". Nesse sentido, o produtor familiar aproveita ao máximo dos recursos disponíveis evitando assim desperdícios.

Dentro da perspectiva ambiental, a agricultura familiar favorece uma maior e melhor distribuição territorial das atividades de exploração do meio, pela melhor possibilidade de adaptação e circunscrição das mesmas a unidades ecológicas mais definidas e homogêneas, mantendo os recursos naturais.

A agricultura familiar mantém uma relação de simbiose com a terra que ela conhece e controla. Ela valoriza as potencialidades do meio implementando suas estratégias de reprodução econômica. O que representa a interação homem-natureza.

A propriedade familiar é uma unidade de produção e consumo, por este motivo valoriza a diversidade, os policultivos, criações, distribuídos de forma equilibrada no espaço e no tempo. O funcionamento econômico da agricultura familiar não se fundamenta na maximização da rentabilidade do capital e na geração de lucro no curto prazo, mas está orientado para o atendimento das necessidades das famílias e para a manutenção do potencial produtivo da terra, percebido como um patrimônio o que visa não somente a obtenção do lucro, mas, sobretudo elevar a qualidade de vida social.

Por ser uma ocupação econômica que combina a exploração familiar e a organização de profissionais, ela incorpora uma estratégia de equilíbrio entre parâmetros econômicos, sociais e ambientais. A agricultura familiar é portadora de grande eficácia coletiva. Através da pluriatividade ela encoraja e favorece o planejamento, o desenvolvimento local e a gestão coletiva dos recursos naturais, sua distribuição eqüitativa e sua administração mais equilibrada e sustentada.

A capacitação dos agricultores familiares, bem como o fortalecimento de suas instituições para o exercício da participação, é um ponto fundamental para o avanço da 
democracia social. Neste sentido é muito importante o conhecimento, pelos agricultores familiares e suas instituições, dos sistemas de tomada de decisão nas instâncias local, regional, nacional e até internacional, para que possam participar ativamente, influir nas políticas macroeconômicas, e se articular com outros agentes sociais, visando a elaboração de políticas setoriais e diferenciadas sustentáveis.

A discussão da noção de sustentabilidade no setor agrícola está associada à constatação, bastante evidente, dos fortes sinais de esgotamento do atual padrão produtivo agrícola dominante. Busca-se, hoje, alternativas que garantam, ao mesmo tempo, a conservação dos recursos naturais em longo prazo, a minimização dos impactos negativos da produção agropecuária sobre o ambiente, a oferta de produtos alimentares e matérias-primas, a garantia e ampliação da renda dos agricultores e a manutenção da diversidade sócio-cultural das comunidades rurais.

Inúmeras definições têm sido concebidas para agricultura sustentável. A dificuldade de se trilhar o caminho da sustentabilidade começa pela própria imprecisão e falta de consenso sobre o termo (ESPINOSA, 1993). No campo concreto das relações sociais o ideal da agricultura sustentável assume conotações diferentes dependendo do segmento social que o emprega: ela é sustentável para quem? Quais são os limites para a sustentabilidade? É necessário e possível estabelecer limites ao desenvolvimento para que a agricultura possa se realizar sobre bases ecologicamente sadias?

Logo, essa diversidade de conotações envolvendo o conceito de sustentabilidade indica que a agricultura sustentável não pode representar apenas um conjunto de técnicas que possam minimizar, em médio prazo, impactos indesejáveis ao ambiente. Ela só faz sentido em um contexto diferente onde a diversidade seja o 'locus' privilegiado das relações físicas e sociais de produção. (CARMO et al., 1995).

Não há como desvencilhar a agricultura familiar do crescimento sustentável apresentado até esse momento. Desenvolve-la e torná-la sustentável somente é possível com uma mudança de comportamento e com o apoio de políticas de incentivo ao agricultor familiar que proporcionem essa mudança. Assim, que essa mudança ocorra surge uma ciência multidisciplinar, capaz de fazer a ligação entre o agricultor e a sustentabilidade, a Agroecologia. 
Dada as discussões precedentes, há uma tendência em visualizar a produção familiar, em sua maioria mesmo sem pleno conhecimento e consciência, praticando uma produção que se aproxima do conceito de sustentabilidade, com tecnologias alternativas (com menor utilização de fertilizantes e agrotóxicos, entre outros) contribuindo em maior proporção à qualidade ambiental. 


\section{MATERIAIS E MÉTODOS}

Este capítulo apresenta os métodos utilizados para o desenvolvimento da pesquisa. São contextualizados o espaço e os instrumentais utilizados bem como as fontes de pesquisa que possibilitaram a construção das análises.

\subsection{Caracterização da área de estudo}

O presente trabalho focou a área de estudo no município de Bauru, estado de São Paulo.

Segundo os dados estatísticos agrícola do município de Bauru estado de São Paulo, concedidos pela Secretaria de Agricultura e Abastecimento, CATI/EA, projeto LUPA do ano de 2007/08 o município, apesar de não ser essencialmente agrícola, possui número de propriedades rurais considerável, sendo que do total de propriedades, 47\% estão na faixa de 5 à 20 ha. Ressalta-se que 67,7\% das propriedades utilizam práticas de conservação de solo quando necessário, 30,8\% faz adubação orgânica e 20,3\% os proprietários residem na própria propriedade.

Esses dados supracitados confirmam informações recolhidas junto ao responsável pela CATI - Bauru/SP. 
A Prefeitura Municipal de Bauru tem desenvolvido ações de apoio ao desenvolvimento agrícola do município, em especial aos produtores caracterizados como familiares. Tais ações tem sido implementadas através de organização de feiras livres diárias, incentivo à compra de produtos produzidos por agricultores familiares com a Declaração de Aptidão ao Pronaf (DAP) para merenda de todas as escolas do município por meio de licitação, organizando eventos com palestras informativas e fornecendo suporte técnico aos agricultores que procuram a Secretaria Municipal da Agricultura e Abastecimento - SAGRA.

\subsubsection{Localização Geográfica de Bauru}

Bauru é um município localizado na região centro-oeste do estado de São Paulo. Fundado em 1896, a uma altitude de 526 m, é hoje centro de um território de 673,5 $\mathrm{km}^{2}$. Suas coordenadas de localização são de longitude entre os meridianos 48 e 50 ao Oeste de Greenwich e latitude entre os paralelos 21, 30 e 23 ao Sul do Equador. A Figura 3 apresenta o mapa de localização de Bauru estado de São Paulo.

Figura 3 - Localização do município de Bauru estado de São Paulo

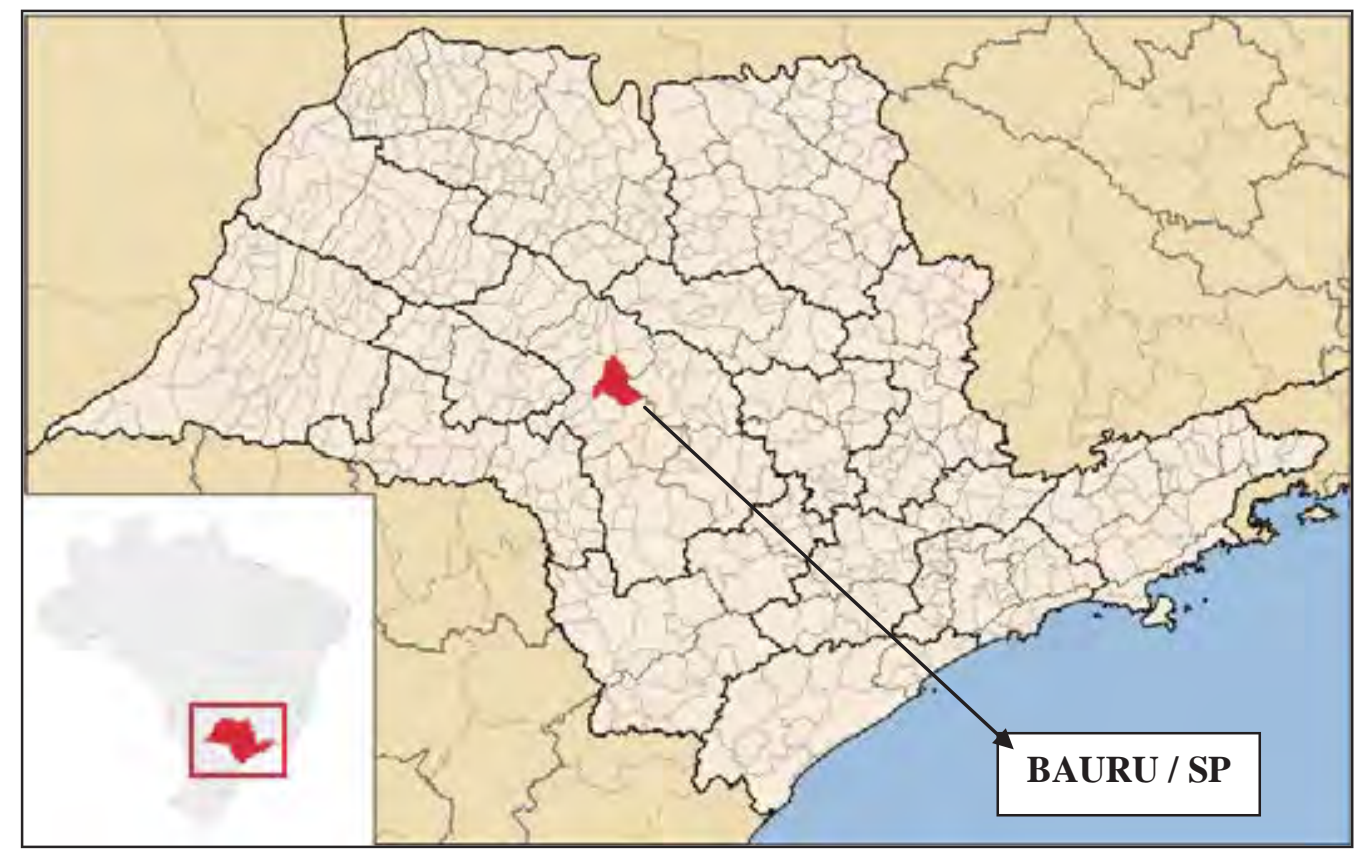

Fonte: Wikipédia (2011) adaptado pelo autor. 


\subsection{Metodologia}

O presente estudo tem um caráter exploratório e foi estruturado no sentido de coletar, qualificar e analisar informações.

A primeira etapa do processo de pesquisa consistiu de uma revisão bibliográfica, tendo como referência bases conceituais dos estudos sobre agricultura familiar, desenvolvimento sustentável, agroecologia, tecnologias convencionais, tecnologias alternativas identificando as barreiras e as mudanças necessárias para formar e transformar paradigmas existentes. Tal procedimento teve por objetivo proporcionar um embasamento teórico ao tema abordado.

Na segunda etapa foi realizada uma pesquisa de campo no município de Bauru/SP com apoio dos órgãos estadual CATI e municipal SAGRA disponibilizando informações para o contato com os agricultores familiares e não familiares.

Tal procedimento teve como objetivo discutir e validar conceitos e posturas sobre o espaço da agricultura familiar frente a conceitos de sustentabilidade.

A entrevista foi realizada de modo presencial onde o pesquisador visitou pessoalmente as propriedades, algumas juntamente com um responsável da Coordenadoria de Assistência Técnica Integral - CATI, outras com o responsável da Secretaria Municipal da Agricultura e Abastecimento - SAGRA e algumas somente a pesquisadora. Utilizou-se de questionário com perguntas abertas e fechadas formuladas a partir do delineamento do objeto, possibilitando aos entrevistados a possibilidade de discorrer sobre o tema proposto, sem respostas ou condições prefixadas pelo pesquisador.

\subsection{Dimensões da sustentabilidade na construção de parâmetros}

Para elaboração do questionário da pesquisa utilizou-se as dimensões apostadas no capítulo 2 item 2.2.1 Indicadores de sustentabilidade o qual aponta as três dimensões da sustentabilidade: a ambiental, a econômica e a sócio-cultural.

Através dessas dimensões elaborou-se parâmetros e variáveis para elaboração do questionário aplicado na pesquisa de campo. Diante das respostas objetiva-se 
identificar qual agricultura mais aproxima sua lógica de produção à uma produção sustentável. Se a familiar ou a não familiar.

\subsubsection{Categoria dimensão ambiental}

Para esta categoria construiu-se três parâmetros:

- Parâmetro solo: o qual tem o intuito de avaliar de modo geral, não específico ou técnico, o grau de qualidade do uso do solo. Para tanto foram adotadas as seguintes variáveis: erosão, curva de nível e proteção ao solo.

- Parâmetro água: o qual tem o intuito de avaliar de modo geral, não específico ou técnico, o grau de qualidade, quantidade e consciência quanto ao uso da água. Para tanto foram adotadas as seguintes variáveis quanto indicador água: origem, uso, qualidade, tratamento, desperdício.

- Parâmetro vegetação: este indicador tem o intuito de verificar dados de preservação. Para tanto foram adotadas as seguintes variáveis: reserva legal e nível de diversidade.

Foram elaboradas questões com bases nos indicadores e variáveis supracitadas. Tem-se o propósito de avaliar e analisar, através das questões, analisar o grau de sustentabilidade que se refere ao parâmetro da dimensão ambiental.

\subsubsection{Categoria dimensão econômica}

Para esta categoria foi elaborado apenas um parâmetro:

- Parâmetro renda: o qual tem o intuito de avaliar a situação econômica da produção. Não foram levantados dados específicos, mesmo porque são de difícil acesso devido a insegurança dos proprietários em fornecê-los. Portanto serviu como base geral para avaliar a situação de sustentabilidade ou não da propriedade pesquisada. Para tanto foram adotadas as seguintes variáveis: valor da produção anual, relação produção/consumo, renda rural agrícola, não agrícola e não rural, cooperativismo e associação. 


\subsubsection{Categoria dimensão sócio-cultural}

Para esta categoria foi elaborado apenas um parâmetro:

- Parâmetro qualidade de vida: este indicador tem o intuito de avaliar a qualidade de vida do produtor. Para tanto foram adotadas as seguintes variáveis: saúde, participação coletiva, educação formal, acesso a equipamentos, moradia, energia elétrica, computador, internet, TV, automóvel, saneamento, grau de satisfação do produtor na atividade exercida e conhecimento quanto ao desenvolvimento sustentável.

Para a construção dos parâmetros e variáveis elaborou-se o questionário semi-estruturado com perguntas abertas e fechadas, o qual foi dividido em cinco partes sendo a primeira referente às informações gerais da propriedade, como nome, endereço, telefone de contato, tipo de propriedade (se familiar ou não familiar) entre outras questões. A segunda parte concentrou-se na caracterização da unidade de produção onde questionou-se quanto ao tamanho da propriedade, atividade exercida entre outras questões. A terceira parte constou de perguntas quanto à categoria da dimensão ambiental. A quarta parte quanto à categoria da dimensão econômica e a quinta e última parte quanto à categoria da dimensão sócio-cultural. O questionário completo consta no anexo A deste trabalho.

\subsection{Processo de seleção das propriedades pesquisadas}

A partir da definição do perfil do produtor - produtores familiares e não familiares, proprietário ou arrendatário, mas não assentados - foi realizada a seleção dos mesmos.

Os responsáveis pela CATI e pela SAGRA contribuíram na elaboração da amostra e dos contatos disponíveis.

Foram realizadas quatorze entrevistas no total, sendo oito em propriedades familiares e seis em propriedades não familiares. 


\subsection{Tratamento dos dados}

De posse de todos os dados coletados através das entrevistas, de observações feitas pelo pesquisador e de material referencial da pesquisa (mapas, livros, periódicos, artigos e outros), procedeu-se às tabulações, correlações e análises necessárias.

Os dados coletados através das entrevistas e expressos tanto de forma quantitativa como qualitativa foram digitados e ordenados em planilhas do Excel. As perguntas das entrevistas foram colocadas nas planilhas de forma sintética, bem como as respostas obtidas.

Ressalta-se que na planilha referente à entrevista com os agricultores constou-se os dados gerais de acordo com os indicadores e variáveis elaborados para cada parâmetro. 


\section{RESULTADOS E ANÁLISE}

A seguir são apresentados os resultados da pesquisa de campo. As entrevistas com produtores familiares e não familiares do município de Bauru foram realizadas no período de agosto a início de outubro de 2011.

\subsection{Caracterizações das propriedades pesquisadas}

Algumas considerações sobre a amostra pesquisada: das14 entrevistas, 8 foram em propriedades familiares e 6 não familiares. Ressalta-se a dificuldade de acesso às propriedades não familiares, sendo as familiares mais acessíveis. Duas propriedades familiares eram de arrendatários e as outras 6 de proprietários. Nas propriedades não-familiares todos eram proprietários.

Das propriedades familiares, 4 possuem Declaração de Aptidão ao Pronaf - DAP. Das que não possuem, os produtores declararam que embora tenham as características para obterem a declaração, a mesma não foi emitida por não haver necessidade.

Para a apresentação dos resultados separou-se a amostra nas duas categorias, considerando as familiares, de um total de oito, e a não familiar, de um total de 
seis. Tal procedimento permite avaliar os dados separadamente para análise de cada resultado de acordo com a categoria e, assim, efetuar um comparativo entre ambas.

Em relação à dimensão dos estabelecimentos visitados, a Tabela 1 mostra que: as familiares estão no extrato de até 50 ha. A maioria das propriedades está abaixo de 30 ha: apenas duas estão no extrato de 30,1 a 50 ha. Já as tradicionais, a totalidade possuía propriedades acima de 100 ha.

Tabela 1 - Dimensão das propriedades, Bauru, 2011.

\begin{tabular}{lccc}
\hline \multirow{2}{*}{$\begin{array}{l}\text { Extrato } \\
\text { de área }\end{array}$} & Familiar & Não familiar & Total \\
\cline { 2 - 4 } & $\mathbf{N}^{\mathbf{0}}$ & $\mathbf{N}^{\mathbf{0}}$ & $\mathbf{N}^{\mathbf{0}}$ \\
\hline Até 10 ha & 3 & 0 & 3 \\
De 10,1 a 30 ha & 3 & 0 & 3 \\
De 30,1 a 50ha & 2 & 0 & 2 \\
De 50,1 a 100ha & 0 & 0 & 0 \\
Acima de 100ha & 0 & 6 & 6 \\
\hline Total & 8 & 6 & 14 \\
\hline
\end{tabular}

Fonte: dados da pesquisa

A tabela 2 mostra a tecnologia de produção utilizada. Nas propriedades familiares nenhuma produzia orgânico, duas estavam em transição, sem certificação e seis caracterizaram sua produção como convencional. Nas tradicionais, a totalidade adotava a tecnologia de produção convencional.

Tabela 2 - Padrão tecnológico

\begin{tabular}{lccc}
\hline \multirow{2}{*}{ Padrão } & Familiar & Não familiar & Total \\
\cline { 2 - 4 } & $\mathbf{N}^{\mathbf{0}}$ & $\mathbf{N}^{\mathbf{0}}$ & $\mathbf{N}^{\mathbf{0}}$ \\
\hline Orgânico & 0 & 0 & 0 \\
Transição & 2 & 0 & 2 \\
Convencional & 6 & 6 & 12 \\
\hline Total & 8 & 6 & 14 \\
\hline Fonte: dados da pesquisa & & &
\end{tabular}


A Tabela 3 mostra que as propriedades familiares desenvolvem atividades de forma mais diversificada.

Tabela 3 - Atividades desenvolvidas

\begin{tabular}{lccc}
\hline \multirow{2}{*}{ Atividades } & Familiar & Não familiar & Total \\
\cline { 2 - 4 } & $\mathbf{N}^{\mathbf{0}}$ & $\mathbf{N}^{\mathbf{0}}$ & $\mathbf{N}^{\mathbf{0}}$ \\
\hline Diversificada & 6 & 6 & 12 \\
Única & 2 & 0 & 2 \\
\hline Total & 8 & 6 & 14 \\
\hline
\end{tabular}

Fonte: dados da pesquisa

Os dados confirmam o aspecto ressaltado na revisão bibliográfica quanto à lógica de produção familiar, onde a maioria das propriedades familiares diversificam sua produção, visando ampliar possibilidades de renda. O estudo confirma essa observação: as propriedades familiares se destacam quanto à diversificação da produção sendo que seis diversificam sua produção, trabalhando com mais de uma atividade agrícola; as duas que responderam trabalhar com apenas uma atividade (horticultura), na realidade desenvolvem uma produção diversificada. Já a não familiar não diversifica a produção e, em sua totalidade, desenvolvem uma única atividade de produção.

A seguir são apresentados os resultados relativos às questões que envolvem os parâmetros de sustentabilidade, nas dimensões ambiental, econômica e sóciocultural.

\subsection{Resultados relativos à categoria dimensão ambiental}

Iniciando a apresentação dos resultados relativos à dimensão ambiental, a tabela 4 mostra dados relativos ao indicador solo. Os dados demonstram que ambas as propriedades fazem algum tipo de tratamento com o solo, tanto a propriedade familiar como a não familiar. Ressalta-se que as propriedades tradicionais pesquisadas nenhuma possui área com erosão, já as familiares das oito pesquisadas, cinco relataram que possuem. Ambas destacaram que fazem algum tipo de tecnologia de proteção ao solo. 
Tabela 4 - Parâmetro Solo

\begin{tabular}{|c|c|c|c|c|c|c|}
\hline \multirow{2}{*}{ CARACTERIZAÇÃO } & \multicolumn{3}{|c|}{ FAMILIAR } & \multicolumn{3}{|c|}{ NÃO FAMILIAR } \\
\hline & SIM & NÃO & TOTAL & SIM & NÃO & TOTAL \\
\hline O imóvel tem curva de nível? & 5 & 3 & 8 & 5 & 1 & 6 \\
\hline O imóvel tem área com erosão? & 3 & 5 & 8 & 0 & 6 & 6 \\
\hline Utiliza de alguma tecnologia de proteção do solo? & 6 & 2 & 8 & 6 & 0 & 6 \\
\hline Faz cobertura vegetal? & 5 & 3 & 8 & 2 & 4 & 6 \\
\hline Faz plantio direto? & 0 & 8 & 8 & 4 & 2 & 6 \\
\hline
\end{tabular}

Nas respostas, em sua maioria os produtores familiares relataram que não utilizam equipamentos e maquinários sofisticados, utilizam recursos simples, manuais. Tais equipamentos dependem da própria força física manual, sendo utilizados com as próprias mãos. Já nas respostas das propriedades não familiares, em sua totalidade utilizam maquinários para a produção, para facilitar e otimizar o trabalho do empregado, maximizando assim os resultados. A familiar é a que mais utiliza tecnologias simples, de acordo com os recursos disponíveis, não adotando tecnologias caras ou sofisticadas ou ainda mecanizadas como a não familiar. Essa tecnologia de produção destaca a proximidade do homem com a natureza, onde o produtor lida com a terra, a produção com as próprias mãos.

$\mathrm{Na}$ maioria das respostas os produtores familiares ressaltaram a afinidade com a terra e que essa afinidade vinha de gerações. Já a não familiar encara a terra como simples campo de produção para comercialização, não existe a relação efetiva de homem - natureza. Mesmo do funcionário contratado, o qual vê seu trabalho apenas como sustento.

A tabela 5 mostra dados relativos ao indicador água. As respostas em sua totalidade foram iguais tanto nas propriedades familiares como tradicionais: todos entrevistados responderam que a água da propriedade não está sujeita a nenhum tipo de contaminação. Também responderam não quando questionados se a propriedade emite alguma contaminação na água. Nenhuma das propriedades entrevistadas faz tratamento ou cuidado com a água. E quando questionado quanto à escassez da água, todas as respostas de ambas as categorias de propriedades foram que não sofrem. 
Tabela 5 - Parâmetro Água

\begin{tabular}{|c|c|c|c|c|c|c|}
\hline \multirow{2}{*}{ CARACTERIZAÇÃO } & \multicolumn{3}{|c|}{ FAMILIAR } & \multicolumn{3}{|c|}{ NÃO FAMILIAR } \\
\hline & SIM & NÃO & TOTAL & SIM & NÃO & TOTAL \\
\hline A água esta sujeita a algum tipo de contaminação? & 0 & 8 & 8 & 0 & 6 & 6 \\
\hline A propriedade emite alguma contaminação na água? & 0 & 8 & 8 & 0 & 6 & 6 \\
\hline Faz algum tipo de tratamento ou cuidade com a água? & 0 & 8 & 8 & 0 & 6 & 6 \\
\hline Sofre com escassez de água? & 0 & 8 & 8 & 0 & 6 & 6 \\
\hline
\end{tabular}

Fonte: dados da pesquisa

Durante a pesquisa, percebeu-se que os produtores tanto familiares como tradicionais quando questionados quanto ao indicador água, demonstraram receio em responder, tendo alguns produtores questionados sobre a finalidade dessas questões. Todos, sem exceção, simplesmente responderam não a todas as perguntas efetuadas, ressaltando a preocupação com a racionalidade do uso da água, bem como cuidados quanto a emissão de algo que pudesse contaminá-la. Em contrapartida, nenhum dos produtores entrevistados informou realizar algum tipo de tratamento ou cuidado com a mesma. De modo geral, por observação pessoal no local, as respostas condizem com o apresentado na propriedade e produtores. Salienta-se que poderiam ser implementados ou melhorados alguns recursos que utilizam as águas, como modo de irrigação, embora tal questão não tenha sido discutida entre pesquisador e entrevistado, apenas observada.

A tabela 6 mostra dados relativos ao indicador vegetação. As respostas quanto a este indicador demonstraram que na propriedade familiar foi maior o índice de respostas positivas quanto às questões levantadas. Quanto a possuir reserva legal na propriedade 5 das propriedades familiares e 4 das propriedades tradicionais responderam que possuem reserva legal na propriedade. Quanto a mata ciliar 6 das familiares e 4 das tradicionais responderam que possuem mata ciliar na propriedade. Quanto à utilização de fertilizantes e agrotóxicos na produção as propriedades familiares entrevistadas as respostas foram metade 4 responderam que utilizam contra 4 que não utilizam. Já nas propriedades tradicionais em sua totalidade 6 utilizam agrotóxico e fertilizante nas propriedades. 
Tabela 6 - Parâmetro Vegetação

\begin{tabular}{lccccccccc}
\hline \multirow{2}{*}{ CARACTERIZAÇÃo } & \multicolumn{3}{c}{ FAMILIAR } & & \multicolumn{3}{c}{ NÃO FAMILIAR } \\
\cline { 2 - 4 } & & SIM & NÃO & TOTAL & & SIM & NÃO & TOTAL \\
\hline A propriedade possui reserva legal? & 5 & 3 & 8 & & 4 & 2 & 6 \\
A propriedade possui mata ciliar? & 6 & 2 & 8 & & 4 & 2 & 6 \\
Utiliza fertilizantes e agrotóxicos na produção? & 4 & 4 & 8 & & 4 & 2 & 6 \\
\hline
\end{tabular}

Fonte: dados da pesquisa

Observou-se que as propriedades adotam tecnologias diferenciadas na produção: algumas, as familiares em maioria, da forma mais simples possível diante dos poucos recursos disponíveis e outras, a maioria das tradicionais, dispondo de tecnologias mais sofisticadas, com uso de maquinários, orientação técnica integral contratada entre outros.

Durante as entrevistas, observou-se pelas respostas dos entrevistados, que os produtores familiares demonstram maior preocupação com o quesito ambiental, seja no modo de responder as questões, prolongando e detalhando as respostas. Quando questionados, por exemplo, se "Utiliza fertilizantes e agrotóxicos na produção", a maioria dos produtores familiares, cada qual de seu modo particular de expressão, respondiam "não" e em seguida tentavam justificar o motivo e ressaltar que não era prejudicial ao solo e ambiente como um todo. Diziam de um modo geral: "fazemos com o máximo cuidado para não agredir a produção e o solo". Já nas respostas das propriedades tradicionais, notou-se maior exatidão nas respostas, respondendo apenas a "sim" e ponto, sem justificativas. Esse fato talvez ocorreu, por não ter sido realizada a entrevista diretamente com o responsável da produção, ou seja, com quem lida na terra, mas sim com o proprietário ou gerente/supervisor.

Assim, os resultados quanto à dimensão ambiental indicam que a maioria das propriedades, tanto familiares como tradicionais adotam algum tipo de tecnologia na produção que contribui para a preservação ambiental, cuidado com o solo, utilização da água. Porém de forma diferenciada para cada tipo de propriedade.

Outro ponto interessante foi quanto à falta de informação, em especial quanto às tecnologias sustentáveis. Em relação aos produtores familiares, a maioria não possui conhecimento quanto a tecnologias sustentáveis disponíveis, e tampouco quanto ao que se refere desenvolvimento sustentável (responderam “não sei” na pergunta 5.1.11 do questionário 
aplicado, em anexo). Já a não familiar, todos os entrevistados procuraram ao menos definir desenvolvimento sustentável.

\subsection{Resultados relativos à categoria dimensão econômica}

Iniciando a apresentação dos resultados relativos à dimensão econômica, a tabela 7 mostra o destino que se dá a produção. Os dados confirmam o descrito por diversos autores, onde os agricultores familiares, em sua totalidade, destinam sua produção tanto para venda como para consumo próprio, ou seja, para o sustento da família. Já as propriedades tradicionais destinam sua produção em sua totalidade para a venda.

Tabela 7 - Destino da produção

\begin{tabular}{lccc}
\hline Destino & Familiar & Não familiar & Total \\
\cline { 2 - 4 } Comercialização & $\mathbf{N}^{\mathbf{0}}$ & $\mathbf{N}^{\mathbf{0}}$ & $\mathbf{N}^{\mathbf{0}}$ \\
$\begin{array}{l}\text { Comercialização e } \\
\text { consumo próprio }\end{array}$ & 0 & 6 & 6 \\
\hline Total & 8 & 0 & 8 \\
\hline Fonte: dados da pesquisa & & 6 & 14 \\
\hline
\end{tabular}

Fonte: dados da pesquisa

Quanto à renda por atividade, foi perguntado o destino da renda obtida da produção: se o produtor utilizava para a própria produção rural ou para outras atividades não rurais e não agrícola. A maioria, tanto para familiares como tradicionais, reinveste na atividade rural: dois produtores (familiar e não familiar) investiam em rural/não rural e dois para rural/não agrícola tanto para familiar como não familiar. Os resultados são mostrados na Tabela 8.

Tabela 8 - Origem da renda obtida

\begin{tabular}{lccc}
\hline \multirow{2}{*}{ Origem } & Familiar & Não familiar & Total \\
\cline { 2 - 4 } & $\mathbf{N}^{\mathbf{0}}$ & $\mathbf{N}^{\mathbf{0}}$ & $\mathbf{N}^{\mathbf{0}}$ \\
\hline Rural & 6 & 4 & 10 \\
Rural e não rural & 1 & 1 & 2 \\
Rural e rural não & 1 & 1 & 2
\end{tabular}




\begin{tabular}{llll} 
agrícola & 8 & 6 & 14 \\
\hline Total & 8 &
\end{tabular}

A Tabela 9 mostra a origem dos recursos financeiros. Mais da metade das unidades familiares utilizavam recursos próprios, mas três unidades utilizavam recursos próprios e de financiamento. Dessas que utilizam o financiamento, a fonte de recursos foi do PRONAF. Já nas tradicionais, a grande maioria também se utilizava apenas de recursos próprios, contra apenas uma que eventualmente se utilizava de recursos financiados para recursos tecnológicos visando aprimorar a produção.

Tabela 9 - Fonte dos recursos

\begin{tabular}{lccc}
\hline \multirow{2}{*}{ Fonte } & Familiar & Não familiar & Total \\
\cline { 2 - 4 } & $\mathbf{N}^{\mathbf{0}}$ & $\mathbf{N}^{\mathbf{0}}$ & $\mathbf{N}^{\mathbf{0}}$ \\
\hline Próprio & 5 & 5 & 10 \\
Próprio e financiado & 3 & 1 & 4 \\
\hline Total & 8 & 6 & 14 \\
\hline Fonte: dados da pesquisa & & &
\end{tabular}

Os resultados mostram uma relevante diferença entre a propriedade familiar e a não familiar. Enquanto a não familiar objetiva o lucro de sua produção, investindo e utilizando a produção somente para comercialização, a familiar visa à sobrevivência da família. Comercializa para sustentar a família, manter a propriedade e ainda consomem os produtos que produzem. Ressalta-se na familiar a proximidade do agricultor com a terra, onde o proprietário é quem produz junto com os membros da família, enquanto que na não familiar a mão-de-obra é contratada. Vale destacar que este resultado confirma o encontrado nas diversas literaturas da revisão bibliográfica.

Ao aplicar o questionário foi perguntado aos produtores familiares se os mesmos, de alguma forma, organizavam os dados da produção, se sabiam qual era o lucro em relação aos custos: todos os produtores familiares responderam que não tinham efetivamente esse controle. Sabiam superficialmente seus custos e lucro. Já a não familiar 
tinham todo controle de custos fixos e variáveis, medindo com maior precisão o lucro com a produção.

Ressalta-se que, mesmo sem o conhecimento de gestão e organização concreta, a agricultura familiar, dada sua lógica particular de produção, é a que mais aproveita em detalhes todos os recursos disponíveis, evitando desperdícios, maximizando assim sua receita, e isso ocorre na maioria dos casos sem o produtor sequer ter idéia desse ponto.

Assim, pode-se dizer que nessa dimensão a que mais se aproxima do quesito sustentabilidade é a agricultura familiar, que não objetiva exclusivamente o lucro.

\subsection{Resultados relativos à categoria dimensão sócio-cultural}

Em relação ao acesso a serviços e produtos, as duas categorias de propriedades pesquisadas têm acesso, porém de forma diferenciada.

Em todas as unidades familiares o produtor e seus familiares residem na propriedade. Já nas unidades de produção não familiar apenas dois residem na propriedade (ressalte-se que nessas duas propriedades apenas o casal, marido e esposa, residem na fazenda: filhos ou demais familiares residem fora da propriedade). Quanto à participação da família na produção, todos, ou a maioria dos familiares nas unidades familiares trabalham e auxiliam na produção. Já nas tradicionais nenhum familiar atua diretamente na produção: toda a produção é realizada com mão-de-obra contratada. Esses dados são mostrados na Tabela 10

Tabela 10 - Participação familiar na produção

\begin{tabular}{lccc}
\hline \multirow{2}{*}{ Característica } & Familiar & Não familiar & Total \\
\cline { 2 - 4 } & $\mathbf{N}^{\mathbf{0}}$ & $\mathbf{N}^{\mathbf{0}}$ & $\mathbf{N}^{\mathbf{0}}$ \\
\hline SIM & 8 & 0 & 8 \\
NÃO & 0 & 6 & 6 \\
\hline Total & 8 & 6 & 14 \\
\hline Fonte: & &
\end{tabular}

Fonte: dados da pesquisa

Vale destacar que, dos entrevistados, todos os proprietários familiares moram e trabalham na propriedade. Já a não familiar a maioria não mora. Apenas dois proprietários, os quais formam por coincidência casais idosos (marido e mulher), optaram por 
morar na propriedade em busca de tranqüilidade e bem estar. Estes residem, porém não trabalham e nem participam diretamente da produção: apenas o marido gerencia a receita em relação ao comercializado. Todo o trabalho no campo da propriedade não familiar, na produção se dá por mão-de-obra contratada e assistência técnica também contratada, com engenheiros agrônomos.

Destaque-se que, durante as entrevistas, foi observado nas respostas, que a maioria dos produtores familiares manifestaram que trabalham por gostar da vida no campo, seja por se tratar de herança familiar, seja porque, em sua maioria, desejam ter uma maior qualidade de vida.

Um dos produtores familiares revelou na entrevista que morava em São Paulo - Capital, era bancário há anos, e por não agüentar mais a pressão constante no trabalho e a rotina corrida na grande São Paulo, decidiu "largar tudo". Como ele próprio mencionou, decidiu vir morar no interior de São Paulo, em propriedade rural e começar uma nova vida, um novo trabalho, em busca de uma vida melhor, com mais qualidade em especial para seus filhos. O mesmo demonstrou com sorriso nos lábios que conseguiu tal objetivo. E enfatizou que não há dinheiro no mundo que pague a vida tranqüila que hoje possui e não a troca por nada.

Essa "ligação com o trabalho" também se verificou em outra entrevista: a propriedade foi herança de família e o casal trabalha na terra assim como os filhos. A mulher, além de ajudar na produção, é quem vai com os filhos, semanalmente, vender os produtos produzidos nas feiras livres do município. Ambos enfatizaram, com orgulho evidente na entrevista, quanto ao trabalho que realizam. Vale destacar que na realização da entrevista foi possível conhecer cada produto que produzem, e do valor dado por esse casal diante de sua produção, bem como do orgulho por fazê-lo.

De um determinado ponto de vista, esses produtores podem ser considerados como "empreendedores": com poucos recursos, mas com uma forte "ligação" ao trabalho e à terra, sua produção tem crescido a cada ano e atualmente estão planejando abrir uma quitanda no centro urbano para comercializar os produtos que produzem. Nesse caso, quem irá gerenciar e trabalhar diariamente na quitanda são os dois filhos do casal. 
Nas entrevistas junto aos produtores tradicionais, na maioria não foi conversado diretamente com o proprietário e sim com o funcionário ou supervisor. Não foi possível notar a mesma relação forte ao trabalho como a notada junto aos produtores familiares. Existe maior frieza, maior receio a responder o questionário, em especial ao quesito econômico e ambiental.

As tabelas 11 e 12 mostram a disponibilidade de bens e serviços relacionados à qualidade de vida para as unidades familiares e tradicionais: energia elétrica, produtos domésticos, utilitários, meios de comunicação e de transporte. A posse destes bens não apresentou resultados diferentes entre as propriedades familiares e tradicionais. Ambas, em sua maioria, tinham acesso a todos os bens e serviços. Esse fato talvez ocorra por se tratar de um município bem localizado e com dotação de recursos.

Tabela 11 - Familiar: acesso a bens e serviços

\begin{tabular}{lccc}
\hline \multirow{2}{*}{ Ítens } & \multicolumn{2}{c}{ Familiar } & \multirow{2}{*}{ Total } \\
\cline { 2 - 3 } & SIM & NÃO & \\
\cline { 2 - 3 } & $\mathbf{N}^{\mathbf{0}}$ & $\mathbf{N}^{\mathbf{0}}$ & $\mathbf{N}^{\mathbf{0}}$ \\
\hline Energia elétrica & 8 & 0 & 8 \\
Equiptos Domésticos & 8 & 0 & 8 \\
Telefone & 8 & 0 & 8 \\
Computador & 6 & 2 & 8 \\
Internet & 7 & 1 & 8 \\
Automóvel & 8 & 0 & 8 \\
\hline
\end{tabular}

Fonte: dados da pesquisa

A tabela 11 mostra que apenas os itens computador e internet não eram disponíveis a todos: duas unidades familiares responderam não possuir computador e 1 (13\%) não possui o serviço de internet. Nesses casos, o computador era utilizado pelos filhos para entretenimento. 
Tabela 12 - Não familiar: acesso a bens e serviços

\begin{tabular}{|c|c|c|c|}
\hline \multirow{3}{*}{ Ítens } & \multicolumn{2}{|c|}{ Não familiar } & \multirow{2}{*}{ Total } \\
\hline & SIM & NÃO & \\
\hline & $\mathrm{N}^{\mathbf{o}}$ & $\mathbf{N}^{\mathbf{0}}$ & $\mathbf{N}^{\circ}$ \\
\hline Energia elétrica & 6 & 0 & 6 \\
\hline Equiptos Domésticos & 6 & 0 & 6 \\
\hline Telefone & 6 & 0 & 6 \\
\hline Computador & 6 & 0 & 6 \\
\hline Internet & 6 & 0 & 6 \\
\hline Automóvel & 6 & 0 & 6 \\
\hline
\end{tabular}

Fonte: dados da pesquisa

Quanto à participação comunitária, a totalidade das unidades familiares participa de ações comunitárias, em sua maioria em igrejas. Já a não familiar apenas uma participa, de um sindicato: todas as demais não tem nenhuma participação comunitária. Os dados são mostrados na Tabela 13.

Tabela 13 - Participação comunitária

\begin{tabular}{lccc}
\hline \multirow{2}{*}{ Participação } & Familiar & Não familiar & Total \\
\cline { 2 - 4 } & $\mathbf{N}^{\mathbf{0}}$ & $\mathbf{N}^{\mathbf{0}}$ & $\mathbf{N}^{\mathbf{0}}$ \\
\hline SIM & 8 & 0 & 8 \\
NÃO & 0 & 6 & 6 \\
\hline Total & 8 & 6 & 14 \\
\hline Fonte: dados da pesquisa & & &
\end{tabular}

Vale ressaltar que a maioria dos produtores familiares entrevistados destacou a importância da participação comunitária, sendo este o maior problema destacado pela maioria dos entrevistados.

Das oito propriedades familiares entrevistadas, sete produtores destacaram que há falta união por parte dos vizinhos. Como um dos produtores enfatizou: "se nós nos uníssemos mais, seria muito bom. Pois uma voz sozinha não é ouvida, enquanto que várias são". Ele mencionou quanto a solicitar ao governo a melhoria das estradas, incentivo a 
cursos técnicos para aprimorar o conhecimento e melhorar a produção entre outras possibilidades. Ressaltou que já tentou certa vez unir os vizinhos, visitou propriedades vizinhas, chegou a marcar uma reunião com todos, os quais confirmaram presença, porém no dia da reunião apenas dois produtores compareceram.

Outros produtores entrevistados fizeram a mesma reclamação perante a vizinhança, ressalta-se que tal informação ocorreu em diferentes pontos do município, ou seja, o problema quanto a falta de união não foi notado em somente um ponto do município. Tal reclamação foi feita também por dois produtores tradicionais.

Outro dado interessante é mostrado na Tabela 14, referente à utilização de serviços públicos (saúde, educação, transporte): a familiar em sua totalidade utiliza, enquanto a não familiar não o faz (a maioria destacou que utiliza serviços particulares).

Tabela 14 - Utilização de serviços públicos

\begin{tabular}{lccc}
\hline \multirow{2}{*}{ Utilização } & Familiar & Não familiar & Total \\
\cline { 2 - 4 } & $\mathbf{N}^{\mathbf{0}}$ & $\mathbf{N}^{\mathbf{0}}$ & $\mathbf{N}^{\mathbf{0}}$ \\
\hline SIM & 8 & 0 & 8 \\
NÃO & 0 & 6 & 6 \\
\hline Total & 8 & 6 & 14 \\
\hline
\end{tabular}

Fonte: dados da pesquisa

Do ponto de vista qualitativo, foi perguntado aos produtores sobre o grau de satisfação com a vida no campo. Apenas para apresentar os dados foi elaborada a Tabela 15. Destaca-se que os produtores familiares em sua totalidade responderam que estão satisfeitos com a vida no campo, a maioria enfatizando a satisfação, realização pessoal e profissional. As propriedades tradicionais apenas um 1 respondeu que não esta satisfeito, o restante 5 estavam satisfeitos. Este produtor não familiar que destacou sua insatisfação com o trabalho no campo explicou a insatisfação dizendo que o retorno financeiro com a produção agrícola é muito baixo. Neste caso, o produtor era um executivo e, ao se aposentar, passou a dedicar-se à produção agrícola que herdou. Segundo o entrevistado, ... "dá muito trabalho e pouco retorno". Este enfatizou que o governo poderia ajudar, em especial quanto a auxílio na formação de preços agrícolas. 
Alguns produtores, tanto familiares como tradicionais, mesmo satisfeitos, argumentaram que poderia haver melhorias, tais como: união entre os vizinhos, melhoria nas estradas para facilitar transporte tanto pessoal, da produção como das peruas escolares, melhorar segurança, e ter maior auxilio do governo.

Tabela 15 - Satisfação com a vida no campo

\begin{tabular}{lccc}
\hline \multirow{2}{*}{ Satisfação } & Familiar & Não familiar & Total \\
\cline { 2 - 4 } & $\mathbf{N}^{\mathbf{0}}$ & $\mathbf{N}^{\mathbf{0}}$ & $\mathbf{N}^{\mathbf{0}}$ \\
\hline SIM & 8 & 5 & 13 \\
NÃO & 0 & 1 & 1 \\
\hline Total & 8 & 6 & 14 \\
\hline Fonte: dados da pesquisa & & &
\end{tabular}

Fonte: dados da pesquisa 


\section{CONSIDERAÇÕES FINAIS}

A revisão bibliográfica e a pesquisa de campo efetuada possibilitaram sistematizar e analisar o grau de aderência dos produtores familiares e não familiares, bem como a adequação das respectivas lógicas de produção frente os parâmetros de sustentabilidade, explicitar aspectos da lógica da produção familiar e sistematizar parâmetros de sustentabilidade no âmbito dessa lógica. Frente aos parâmetros de sustentabilidade, nas suas dimensões ambiental, econômica e sócio-cultural, foi possível elaborar tabelas para avaliação de aderência à sustentabilidade da propriedade familiar frente a não familiar. Com os resultados de pesquisa junto aos produtores familiares e tradicionais, foi analisado a associação da lógica de produção familiar e sua aderência aos indicadores de sustentabilidade, propostos como objetivos do trabalho.

A pesquisa de campo efetuada indica que a agricultura familiar é a que mais se aproxima de uma produção sustentável, se comparada à agricultura não familiar, em todas as dimensões de sustentabilidade pesquisadas. Já a não familiar se aproxima somente de modo equilibrado em alguns aspectos da dimensão ambiental: nas demais dimensões, econômica e sócio-cultural, a que mais se aproxima sustentavelmente é a familiar.

Assim confirmar a hipótese levantada de que a produção familiar dispõe de condições mais favoráveis no atendimento dos requisitos da diversidade, do manejo 
equilibrado dos agroecossistemas e da ocupação da força de trabalho, preconizados pelo paradigma da sustentabilidade.

Os produtores familiares, mesmo sem o devido conhecimento, adoção de práticas efetivas de gestão como o planejamento, organização e controle, produzem, comercializam e sustentam sua propriedade e família com o diferencial: extrema satisfação e orgulho pessoal.

Nesse sentido, é importante questionar se esse produtor tiver maior acesso a informação, suporte técnico, maior apoio do governo, maior subsidio, as possibilidades de sobrevivência e crescimento econômico não seriam maiores. Ressalte-se que esse desenvolvimento poderá se dar por um caminho que destaca não somente o lucro, mas o desenvolvimento sustentável.

Finalmente, considera-se que o presente estudo não teve a pretensão de esgotar um assunto tão complexo e caracterizado por uma heterogeneidade tão grande do grau de inserção da agricultura familiar frente ao desenvolvimento sustentável. Mas coloca em evidência e destaca o rico potencial de exploração agrícola que o nosso país possui, e da necessidade de estudos que relevem essa diferença e possibilidade de inserção sustentável de pequenos produtores na nossa sociedade. 


\section{REFERÊNCIAS}

ANDRIOLI, A. I. A dimensão educativa da agroecologia na agricultura familiar. Revista Espaço Acadêmico, Maringá, n. 85, 2008. Disponível em:

<http://www.espacoacademico.com.br/085/85andrioli.pdf>. Acesso em: 27 fev. 2011.

ALMEIDA, J. A construção social de uma nova agricultura: tecnologia agrícola e movimentos sociais no sul do Brasil. 2. ed. Porto Alegre: Editora da UFRGS, 2009. 210 p.

ALTIERI, M. Agroecologia: bases científicas para uma agricultura sustentável. Guaíba: Agropecuária, 2002. 595 p.

ALTIERI, M. Agroecologia: a dinâmica produtiva da agricultura sustentável. 2. ed. Porto Alegre: Editora da UFRGS, 2000. 114 p.

ALTIERI, M.; YURJEVIC, A. La agroecologia y el desarrollo rural sostenible em America Latina. Agroecologia Y Desarrollo, Santiago, v. 1, p. 25-36, 1991.

AUBERT, C. Agricultura orgânica. In: ENCONTRO BRASILEIRO DE AGRICULTURA ALTERNATIVA, 2., 1985, Rio de Janeiro. Anais... Rio de Janeiro: FAEAB, 1985. p. 21-45.

BASSO, Z. F. C. Análise energética da produção de leite bovino em explorações familiares na região de Botucatu-SP. 2007. 304 f. Dissertação (Mestrado em Agronomia/Energia na Agricultura)-Faculdade de Ciências Agronômicas, Universidade Estadual Paulista, Botucatu, 2007.

BEUS, C. E.; DUNLAP, R. E. Agricultura convencional versus alternativa: as raízes paradigmáticas do debate. Rural Sociology, Knoxville, v. 55, n. 4, p. 590-616, 1990. 
BICALHO, A. M. S. M. Desenvolvimento rural sustentável. In: ENCONTRO NACIONAL DE GEOGRAFIA AGRÁRIA, 13., 1996, Diamantina. Resumos... Diamantina: UFMG, 1996. p. 177-179.

BRASIL. Ministério de Integração Nacional. Produção agroecológica integrada sustentável (PAIS). Brasília, DF, 2011. Disponível em:

<http://www.integracao.gov.br/programasregionais/publicacoes/pais.asp>. Acesso em: 10 jul. 2011.

BRASIL. Ministério do Desenvolvimento Agrário. Agricultura familiar no Brasil e o censo agropecuário 2006. Brasília, DF, 2006. Disponível em: <

http://sistemas.mda.gov.br/portal/index/show/index/cod/1816/codInterno/22598\#>. Acesso em: 23 ago. 2011.

BUAINAIN, A. M.; ROMEIRO, A. A agricultura familiar no Brasil: agricultura familiar e sistemas de produção. Brasília, DF: Incra, 2000. 62 p. Projeto: UTF/BRA/051/BRA.

BUARQUE, A. S. Construindo o desenvolvimento local sustentável: metodologia de Planejamento. Rio de Janeiro: Garamond, 2002. 177 p.

CAPORAL, F. R. Agroecologia: alguns conceitos e princípios. Brasília, DF: MDA/SAF/DATER-IICA, 2004. 24 p.

CARMO, M. S. do; OLIVEIRA SALLES, J. T. A.; COMITRE, V. Agricultura sustentável e o desafio da produção de alimentos no limiar do terceiro milênio. Informações Econômicas, São Paulo, v. 25, n. 11, p. 25-36, 1995.

CARON, P.; SABOURIN, E. Camponeses do sertão: mutação das agriculturas familiares no Nordeste do Brasil. Brasília, DF: EMBRAPA Informação Tecnológica, 2003. 293 p.

CARVALHO, M. A. T.; FANI, W. S.; FERREIRA, W. V. Agroecologia e agricultura familiar. In: ___ Agroecologia. Brasília, DF: Pronaf, 2005. Disponível em: <http://www.pronaf.gov.br/dater/arquivos/Agroecologia.pdf>. Acesso em: 26 set. 2010.

COSTA, H. S. Tecnologia apropriada para a agricultura familiar sustentável do semi-árido brasileiro: bombeamento solar de água para irrigação localizada. In: ENCONTRO DE ENERGIA NO MEIO RURAL, 6., 2006, Campinas. Proceedings online... Disponível em: $<$ http://www.proceedings.scielo.br/scielo.php?script=sci_arttext\&pid=MSC00000000220060 00200044\&lng=en\&nrm=abn>. Acesso em: 26 set. 2010.

DENARDI, R. A. et al. Fatores que afetam o desenvolvimento local em pequenos municípios do Paraná. Curitiba: EMATER, 2000. Disponível em:

<http://www.cria.org.br/gip/gipaf/itens/publ/artigos_trabalhos.html>. Acesso em: 26 set. 2010. 
ESPINOSA, H. R. M. Desenvolvimento e meio ambiente sob nova ótica. Ambiente, São Paulo, v. 7, n. 1, p. 40-44, 1993.

GLIESSMAN, S. R. Agroecologia: processos ecológicos em agricultura sustentável. Porto Alegre: Editora UFRGS, 2000. 653 p.

GLIESSMAN, S. R. Agroecologia: processos ecológicos em agricultura sustentável. 2. ed. Porto Alegre: Editora UFRGS, 2001. 653 p.

GLIESSMAN, S. R. Agroecologia: processos ecológicos em agricultura sustentável. 3 ed. Porto Alegre: Editora UFRGS, 2005. 653 p.

GONÇALVES, J. S.; SOUZA, S. A. M. Agricultura familiar: limites do conceito e evolução do crédito. São Paulo: Instituto de Economia Agrícola, 2005. Disponível em:

$<$ http://www.iea.sp.gov.br/out/verTexto.php?codTexto=2521>. Acesso em: 11 jul. 2009.

GUANZIROLI, C. et al. Agricultura familiar e reforma agrária no século XXI. Rio de Janeiro: Garamond, 2001. 284 p.

GUANZIROLI, C.; CARDIM, S. E. (Coord.). Novo retrato da agricultura familiar: o Brasil redescoberto. Brasília, DF: INCRA, 2000. 74 p. Projeto de Cooperação Técnica FAO/INCRA. Disponível em: <http://www.incra.gov.br/fao/pub3.html>. Acesso em: 11 jul. 2009.

GUIMARÃES, R. P. A ética da sustentabilidade e a formulação de políticas de desenvolvimento. In: VIANA, G.; SILVA, M.; DINIZ, N. O desafio da sustentabilidade. São Paulo: Fundação Perseu Abromo, 2001. p. 43-71.

CASADO, G. G.; MOLINA G.; GUZMAN, S. (Coord.). Introducción a la agroecología como desarrollo rural sostenible. Madrid: Mundi-Prensa, 2000. 535 p.

HECHT, S. La evolución del pensamiento agroecológico. In: ALTIERI, M. Agroecologia: bases agroecologicas para o desenvolvimento sustentável. Montevideo: Editorial NordanComunidad, 1999. p. 338.

JESUS, E. L. Histórico e filosofia da agricultura alternativa. Proposta, Rio de Janeiro, v. 27, p. 34-40,1985.

KARAM, K. F. A agricultura orgânica como estratégia de novas ruralidades: um estudo de caso na região metropolitana de Curitiba. In: ENCONTRO DA SOCIEDADE BRASILEIRA DE SISTEMAS DE PRODUÇÃO, 5., SIMPÓSIO LATINO-AMERICANO SOBRE INVESTIGAÇÃO E EXTENSÃO EM SISTEMAS AGROPECUÁRIOS, 5., 2002, Florianópolis. Disponível em: <http://www.planetaorganico.com.br/TrabKaren1.htm>. Acesso em: 26 set. 2010. 
KAREIVA, P.; MARVIER, M. Conservação voltada para as pessoas. Scientific American Brasil, São Paulo, n. 66, p. 66-73, 2007.

KHATOUNIAN, C. A. A reconstrução ecológica da agricultura. Botucatu: Agroecológica, 2001. 348 p.

LIMA, E. V. L. Alternativas na geração de energia: agricultura familiar e biodigestores. 2009. 93 f. Dissertação (Mestrado em Sociedade, Tecnologia e Meio Ambiente)-Centro Universitário de Anápolis, Instituto Superior de Educação, Unievangelica, Anápolis, 2009.

MOREIRA, R. J. Agricultura familiar e assentamentos rurais: competitividade, tecnologia e integração social. In: FERREIRA, A. D. D.; BRANDENBURG, A. E. (Org.). Para pensar outra agricultura. Curitiba: UFPR, 1998. p. 171-195.

OLIVEIRA, J. T. A. Lógicas produtivas e impactos ambientais: estudo comparativo de sistemas de produção. 2000. 284 f. Tese (Doutorado em Engenharia Agrícola)- Faculdade de Engenharia Agrícola, Universidade Estadual de Campinas, Campinas, 2000.

PASCHOAL, A. D. Produção orgânica de alimentos: agricultura sustentável para os séculos XX e XXI. Piracicaba: Adilson D. Paschoal, 1994. 191 p.

PINHEIRO, G. S. R. Agricultor familiar e projeto agroecológico de vida. 2004. 134 f.

Dissertação (Mestrado em Sociologia)- Setor de Ciências Humanas, Letras e Artes, Universidade Federal do Paraná, Curitiba, 2004.

PRODUÇÃO agroecológica integrada sustentável: mais alimento, trabalho e renda no campo: saiba como produzir alimentos saudáveis e preservar o meio ambiente: cartilha. Brasília, DF: Fundação Banco do Brasil, 2008. 24 p.

PIRES, M. O. A trajetória do conceito de desenvolvimento sustentável na transição de paradigmas. In: DUARTE, L. M. G.; BRAGA, M. L. de S. Tristes cerrados: sociedade e biodiversidade. Brasília, DF: Paralelo 15, 1998. p. 65-92.

REINJNTJES, C.; HAVERKORT, B.; WATERS-BAYER, A. Agricultura para o futuro: uma introdução à agricultura sustentável e de baixo uso de insumos externos. Trad.: John Cunha Comerford. Rio de Janeiro: AS-PTA, 1994.

SACHS, I. Brasil e os riscos da modernidade. Ciência Hoje, Rio de Janeiro, v. 20, n. 119, p. 12-14, 1996.

SCHNEIDER, S. Agricultura familiar e pluriatividade. 1999. 470 f. Tese (Doutorado em Sociologia)-Universidade Federal do Rio Grande do Sul, Porto Alegre, 1999.

SCHNEIDER, S. Teoria social, agricultura familiar e pluriatividade. Revista Brasileira de Ciências Sociais, São Paulo, v. 18, n. 51, p. 99-121, 2003. 
SEBRAE AGRONEGÓCIOS. Tecnologia social inovadora traz melhoria de vida para agricultores de baixa renda do Brasil. Revista Sebrae Agronegócios, São Paulo, n. 8, abr. 2008. Disponível em:

<http://www.biblioteca.sebrae.com.br/bds/BDS.nsf/DD5DB33647F7059A832576C60064C4A 0/\$File/NT00043B22.pdf>. Acesso em: 10 jul. 2011.

SEÓ, E. H. Unidade da vida. manual de agricultura natural. São Paulo: Espade, 1984. 195 p.

SOUZA, N. J. Desenvolvimento econômico. 5. ed. São Paulo: Atlas, 2005. 313 p.

TEIXEIRA, J. C. Modernização da agricultura no Brasil: impactos econômicos, sociais e ambientais. Revista Eletrônica da Associação dos Geógrafos Brasileiros, Três Lagoas, MS, v. 2, n. 2, set. 2005. Disponível em: <http://www.cptl.ufms.br/geo/revistageo/Revista/Revista_ano2_numero2/jodenir.pdf>. Acesso em: 15 jan. 2011.

TRENTIN, I. C. L.; WESZ JUNIOR, V. J. Desenvolvimento e agroindústria familiar. In: JORNADA DE ANTROPOLOGIA RURAL, 1., 2005, San Pedro de Cololau. Anais... Porto Xavier: A Gazeta do Povo, 2005. Disponível em:

$<$ http://www.filo.unt.edu.ar/centinti/cehim/jornadas_antrop/desenvolvimento\%20e\%20agroin dustria\%20familair.pdf>. Acesso em: 26 set. 2010.

VEIGA, J. E. et.al. O Brasil rural precisa de uma estratégia de desenvolvimento. Brasília, DF: Convenio FIPE - IICA (MDA/CNDRS/NEAD), 2001. 104 p. Disponível em:

$<$ http://www.nead.org.br/index.php?acao=bibliotecaepublicacaoID=112>. Acesso em: 18 jul. 2009.

VERONA, L. A. F. Avaliação de sustentabilidade em agroecossistemas de base familiar e em transição agroecológica na região sul do Rio Grande do Sul. 2008. 193 f. Tese (Doutorado em Ciências/Produção Vegetal)-Universidade Federal de Pelotas, Pelotas, 2008.

WANDERLEY, M. N. B. A agricultura familiar no Brasil: um espaço em construção. Reforma Agrária, Campinas, v. 25, n. 2/3, p. 37-47, 1995.

WANDERLEY, M. N. B. A valorização da agricultura familiar e a reivindicação da ruralidade no Brasil. In: . Desenvolvimento e meio ambiente: a reconstrução da ruralidade e a relação sociedade/natureza. Curitiba: Editora da UFPR, 2000. p. 29-37.

WIKIPEDIA. Ficheiro: SaoPaulo Municip Bauru.svg. 2011. Disponível em: <http://pt.wikipedia.org/wiki/Ficheiro:SaoPaulo_Municip_Bauru.svg>. Acesso em: 26 set. 2010. 
APÊNDICES 


\section{APÊNDICE A - Questionário aplicado na pesquisa de campo}

\section{unesp}

\section{QUESTIONÁRIO}

(USO EXCLUSIVO PARA PESQUISA DE TRABALHO ACADÊMICO)

DATA DA ENTREVISTA:

INDICADO POR: Nome responsável:

\section{I - INFORMACÕES GERAIS:}

Nome do entrevistado

(responsável):

Nome da propriedade:

Endereço:

Condições de acesso: ( ) bom （ ) regular （）precário

Obs.:

Contatos: Tel: E-mail:

Certificação: orgânico ( ) transição ( ) convencional ( )

Certificadora:

Tipo de propriedade: ( ) familiar * ( ) não familiar

(*)Possui DAP (Declaração de Aptidão ao Pronaf): ( ) sim ( ) não

\section{II - CARACTERIZAC̄̃̃O DA UNIDADE DE PRODUCC̃̃O}

2.1 Tamanho da propriedade: ha

2.2 Posse da terra (ha)

( ) Proprietário ha

( ) Arrendatário ha

( ) Outra ha

2.3 Atividades de produção desenvolvidas:

( ) atividade única. Especificar:

( ) diversifica a produção. Especificar:

2.4 O agricultor sempre trabalhou com agricultura?

( ) Sim ( ) Não. Qual era sua atividade anterior? 
2.5 Desde quando o agricultor trabalha com essa(s) atividade(s)?

2.6 Por que optou pela agricultura?

III - CATEGORIA DA DIMENSÃO AMBIENTAL

\subsection{PARÂMETRO SOLO}

\begin{tabular}{|c|c|c|c|c|c|}
\hline \multicolumn{2}{|c|}{ O imóvel tem curva de nível? } & \multicolumn{2}{|c|}{ O imóvel tem área com erosão? } & \multicolumn{2}{|c|}{$\begin{array}{l}\text { Utiliza de alguma tecnologia de proteção } \\
\text { do solo? }\end{array}$} \\
\hline $\begin{array}{c}\text { SIM } \\
()\end{array}$ & $\begin{array}{c}\mathrm{NÃO} \\
(\text { ) }\end{array}$ & $\begin{array}{c}\text { SIM } \\
(\mathrm{C})\end{array}$ & $\begin{array}{c}\mathrm{NÃO} \\
(\text { ) }\end{array}$ & $\begin{array}{l}\text { SIM } \\
(\mathrm{)}\end{array}$ & $\begin{array}{l}\text { NÃO } \\
(\text { ) }\end{array}$ \\
\hline $\begin{array}{l}\text { O proprietár } \\
\text { ( ) Sim. } \\
\text { ( ) Não. Qu }\end{array}$ & & \multicolumn{2}{|l|}{$\begin{array}{l}\text { ( ) Grande } \\
\text { ( ) Pequena } \\
\text { ( ) Muitas }\end{array}$} & \multicolumn{2}{|c|}{$\begin{array}{l}\text { - Faz cobertura vegetal } \\
\text { ( ) Sim ( ) Não } \\
\text { - Faz plantio direto? }\end{array}$} \\
\hline
\end{tabular}

\subsection{PARÂMETRO ÁGUA}

3.2.1 Fontes de água com origem na propriedade

\begin{tabular}{|c|c|c|c|c|c|c|}
\hline Nascente & $\begin{array}{c}\text { Poço } \\
\text { artesiano }\end{array}$ & $\begin{array}{c}\text { Poço } \\
\text { escavado }\end{array}$ & Córrego & Rio & Lago & Açude \\
\hline$(~)$ & ( & $(\mathrm{)}$ & $(\mathrm{)}$ & $(\mathrm{)}$ & $(\mathrm{)}$ & $(\mathrm{)}$ \\
\hline
\end{tabular}

3.2.2 Fontes de água com origem externa à propriedade

\begin{tabular}{|c|c|c|c|c|c|c|c|}
\hline Serviço público & Nascentes & $\begin{array}{c}\text { Poço } \\
\text { artesiano }\end{array}$ & $\begin{array}{c}\text { Poço } \\
\text { escavado }\end{array}$ & Córrego & Rio & Lago & Açude \\
\hline$(~)$ & $(~)$ & $(~)$ & () & $(~)$ & $(~)$ & $(~)$ & $($ ) \\
\hline
\end{tabular}

\subsubsection{Qualidade}

A água utilizada está sujeita a algum tipo de contaminação? Sim ( ) Não ( )

Qual ?

A propriedade emite alguma contaminação nos corpos de água? Sim ( ) Não ( ) Qual ? 
Faz algum tipo de tratamento ou cuidado com a água? Sim ( ) Não ( )

Qual ?

3.2.4 Sofre com escassez de água?

\begin{tabular}{|c|c|c|c|c|}
\hline Freqüentemente & $\begin{array}{c}\text { Com secas curtas } \\
(20 \text { a 30dias })\end{array}$ & $\begin{array}{c}\text { Com secas médias } \\
(30 \text { a 90dias })\end{array}$ & $\begin{array}{c}\text { Com secas longas } \\
(+ \text { de } 90 \text { dias })\end{array}$ & Nunca \\
\hline$(~)$ & $(~)$ & $(~)$ & $(~)$ & () \\
\hline
\end{tabular}

3.2.5 O produtor tem noção do volume da água que consume? Volume por tempo (litro / hora, dia)

\begin{tabular}{|l|c|c|c|c|}
\hline Consumo doméstico & $\begin{array}{c}\text { Limpeza de } \\
\text { instalações }\end{array}$ & Irrigação & $\begin{array}{c}\text { Beneficiamento de } \\
\text { produtos }\end{array}$ & animais \\
\hline & & & & \\
\hline
\end{tabular}

\subsection{PARÂMETRO VEGETAÇÃo}

3.3.1 A propriedade possui reserva legal?

( ) Não ( ) Sim (__ \% da área total da propriedade)

3.3.2 A propriedade possui mata ciliar? ( ) Sim （ ） Não

3.3.3 Utiliza fertilizantes e agrotóxicos na produção? ( ) Sim ～～） Não

\section{IV - CATEGORIA DA DIMENSÃO ECONÔMICA}

\subsection{PARÂMETRO RENDA}

4.1.1 Destino da produção:

( ) comercialização _ _ \% ( ) consumo próprio __ \% ～（ ） comercialização e consumo próprio __ \%

4.1.2 Qual o valor de sua última produção/safra?

4.1.3 Da renda total qual a participação (em \%) de:

( ) atividade rural agrícola__\% ( ) atividade rural não agrícola__\% ( ) atividade não rural _ \%

4.1.4 Trabalha com alguma cooperativa?

( ) Não ( ) Sim. Qual?

4.1.5 Trabalha com alguma associação?

( ) Não ( ) Sim. Qual?

4.1.6 Participação (\%) do uso de recursos próprios e financiado na produção?

( ) recursos próprios_\% $\quad$ ( ) recursos financiado__\% $\quad$ ( ) recursos próprios e financiado_ \% 
4.1.7 Existe fácil acesso a recursos financeiros para investimento na produção?

( ) Não ( ) Sim. Qual?

\section{V - CATEGORIA DA DIMENSÃO SÓCIO-CULTURAL}

\subsection{PARÂMETRO QUALIDADE DE VIDA}

5.1.1 O agricultor mora na propriedade?

( ) Sim, mora. ( ) Não, mora em outra propriedade rural （ ） Não, mora no centro urbano

5.1.2 Número de pessoas que trabalham na propriedade: $(\quad$ )

Dessas pessoas, descrever abaixo, as que fazem parte da família:

\begin{tabular}{|c|c|c|c|c|c|c|c|}
\hline \multicolumn{2}{|r|}{ Nome } & $\begin{array}{c}\text { Parentesco } \\
\text { em relação ao }\end{array}$ & $\begin{array}{l}\text { Naturalidade } \\
\text { (município e }\end{array}$ & $\begin{array}{c}\text { Sexo } \\
\text { M-masc } \\
\text { F-fem }\end{array}$ & Idade & $\begin{array}{l}\text { Escolaridade } \\
\text { (série a graw }\end{array}$ & Tarefas principais \\
\hline 1 & & & & & & & \\
\hline 2 & & & & & & & \\
\hline 3 & & & & & & & \\
\hline 4 & & & & & & & \\
\hline 5 & & & & & & & \\
\hline 6 & & & & & & & \\
\hline 7 & & & & & & & \\
\hline 8 & & & & & & & \\
\hline 9 & & & & & & & \\
\hline 10 & & & & & & & \\
\hline
\end{tabular}

5.1.3 Há mão-de-obra de terceiros? ( ) Sim. Quantidade:

( ) Não 
5.1.4 Infra-estrutura do lar:

\begin{tabular}{|c|c|c|c|c|c|c|c|c|}
\hline $\begin{array}{c}\text { Moradia } \\
\text { (1) }\end{array}$ & $\begin{array}{c}\text { Água } \\
\text { (2) }\end{array}$ & $\begin{array}{c}\text { Esgoto } \\
\text { (3) }\end{array}$ & $\begin{array}{c}\text { Lixo } \\
\text { Orgânico } \\
\text { (4) }\end{array}$ & $\begin{array}{c}\text { Lixo } \\
\text { Comum } \\
\text { (4) }\end{array}$ & $\begin{array}{c}\text { Energia } \\
\text { Elétrica } \\
\text { (Sim ou } \\
\text { Não) }\end{array}$ & $\begin{array}{c}\text { Equipamentos } \\
\text { domésticos } \\
\text { (5) }\end{array}$ & $\begin{array}{c}\text { Veículos } \\
\text { (6) }\end{array}$ & $\begin{array}{c}\text { Informações } \\
\text { gerais } \\
\text { (Principais } \\
\text { fontes) } \\
\text { (7) }\end{array}$ \\
\hline & & & & & & & & \\
\hline
\end{tabular}

(1) 1 - boa; 2 - razoável; 3 - ruim

(2) 1 - rede pública; 2 - poço escavado; 3 - poço artesiano; 4 - fonte protegida ; 5 - fonte sem proteção; 6 - outro

(3) 1 - fossa séptica; 2 - fossa seca; 3 - fossa negra; 4 - fossa aérea; 5 - outro

(4) 1 - recicla; 2 - queima; 3 - joga em terreno/rio; 4 - enterra; 5 - coleta pública; 6 - outro

(5) 1 - fogão a gás; 2 - fogão a lenha; 3 - geladeira; 4 - freezer; 5 - batedeira / liquidificador; 6 - televisão; 7 rádio; 8 - aparelho de som; 9 - telefone; 10 - computador; 11 - outros

(6) 1 - carro de passeio; 2 - veículo de transporte de mercadorias; 3 - moto; 4 - bicicleta; 5 - carroça; 6 - cavalo; 8 - outros

(7) 1 - jornal; 2 - televisão; 3 - rádio; 4 - internet; 5 - igreja; 6 - outros

5.1.5 Acesso a serviços formais/públicos (assinalar com "x")

\begin{tabular}{|l|l|l|l|l|l|l|}
\hline & \multicolumn{3}{|c|}{ Local disponível } & \multicolumn{3}{c|}{ Qualidade do serviço } \\
\hline & Comunidade & $\begin{array}{c}\text { Sede do } \\
\text { Município }\end{array}$ & $\begin{array}{c}\text { Outra } \\
\text { Cidade }\end{array}$ & Boa & Razoável & Ruim \\
\hline Escola & & & & & & \\
\hline Médico & & & & & & \\
\hline Dentista & & & & & & \\
\hline Transporte & & & & & \\
\hline
\end{tabular}

5.1.6 Participação comunitária

\begin{tabular}{|c|c|c|c|}
\hline $\begin{array}{c}\text { Há na localidade } \\
\text { associações, sindicato, } \\
\text { produtores, moradores, } \\
\text { igreja etc)? Qual e com } \\
\text { que propósito? }\end{array}$ & $\begin{array}{c}\text { O agricultor ou alguém } \\
\text { da propriedade } \\
\text { participa? }\end{array}$ & $\begin{array}{c}\text { Seus vizinhos } \\
\text { participam? } \\
\text { (1) }\end{array}$ & $\begin{array}{c}\text { A vizinhança é } \\
\text { na maioria: } \\
\text { (2) }\end{array}$ \\
\hline & & & \\
\hline
\end{tabular}

(1) 1 = sim; 2 = não; 3 = não sabe

(2) 1 = parentes; 2 = amigos; 3 = conhecidos; 4 = desconhecidos

5.1.7 Existe assistência técnica para a produção?

( ) Não ( ) Sim. Qual?

5.1.8 O governo auxilia de alguma forma à produção?

( ) Não

( ) Sim. Especifique nível de governo e de que forma auxilia: 
5.1.9 Está satisfeito com a vida no campo?

( ) Sim ( ) Não

Especifique o motivo:

5.1.10 O que poderia ser melhorado?

5.1.11 O que você entende por desenvolvimento sustentável? 
APÊNDICE B

Planilha com respostas dos produtores quanto ao questionário 


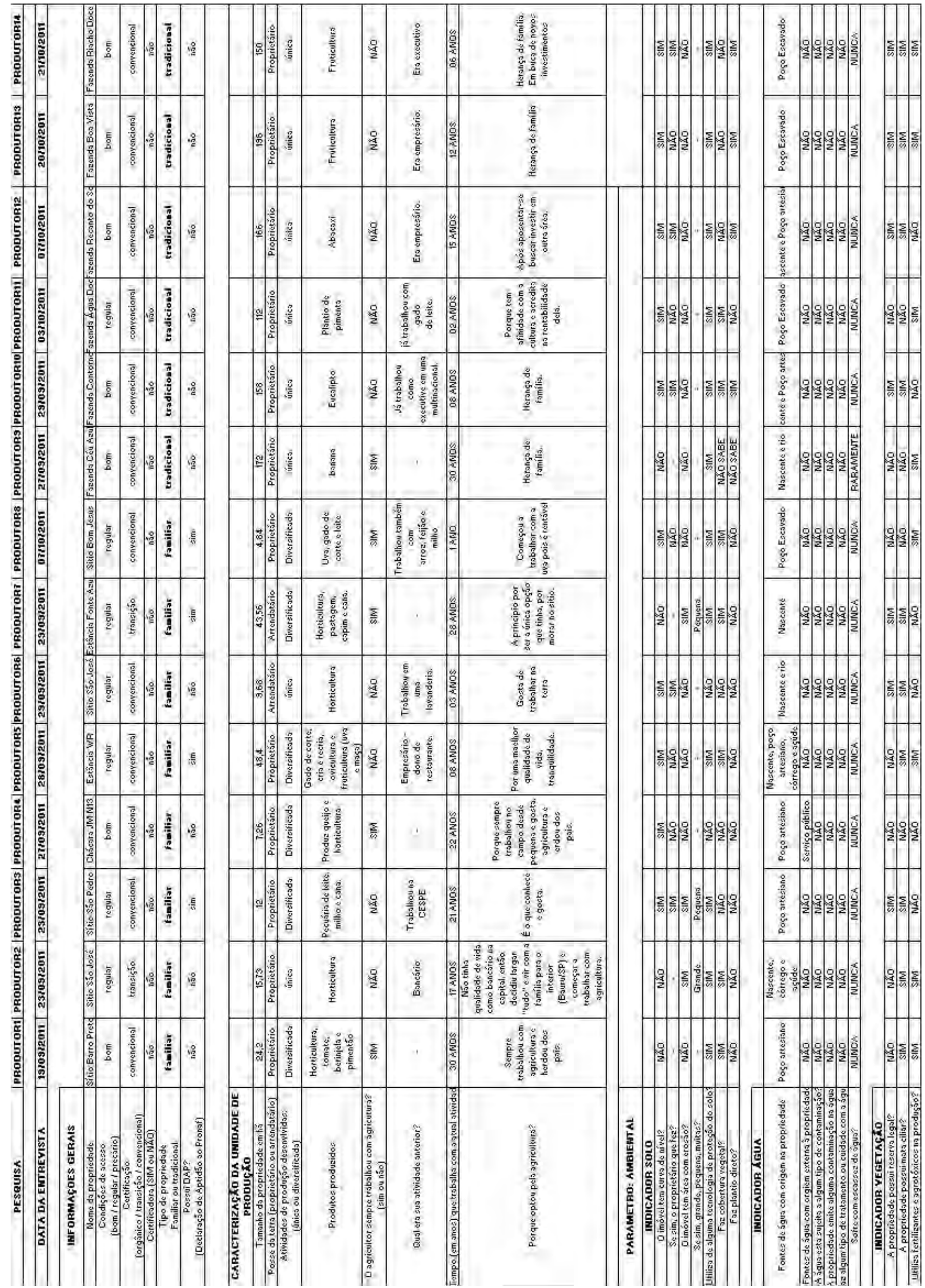




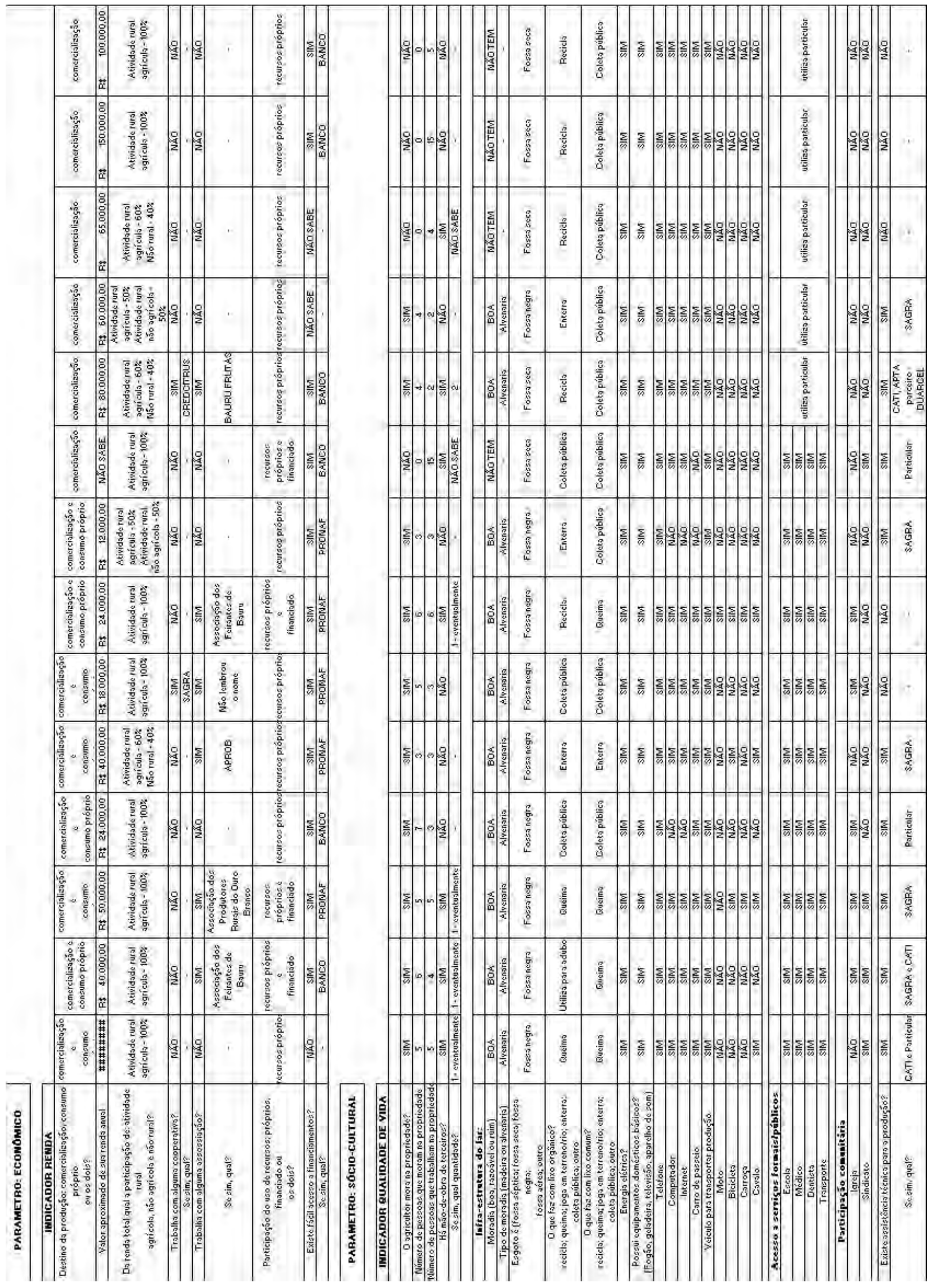




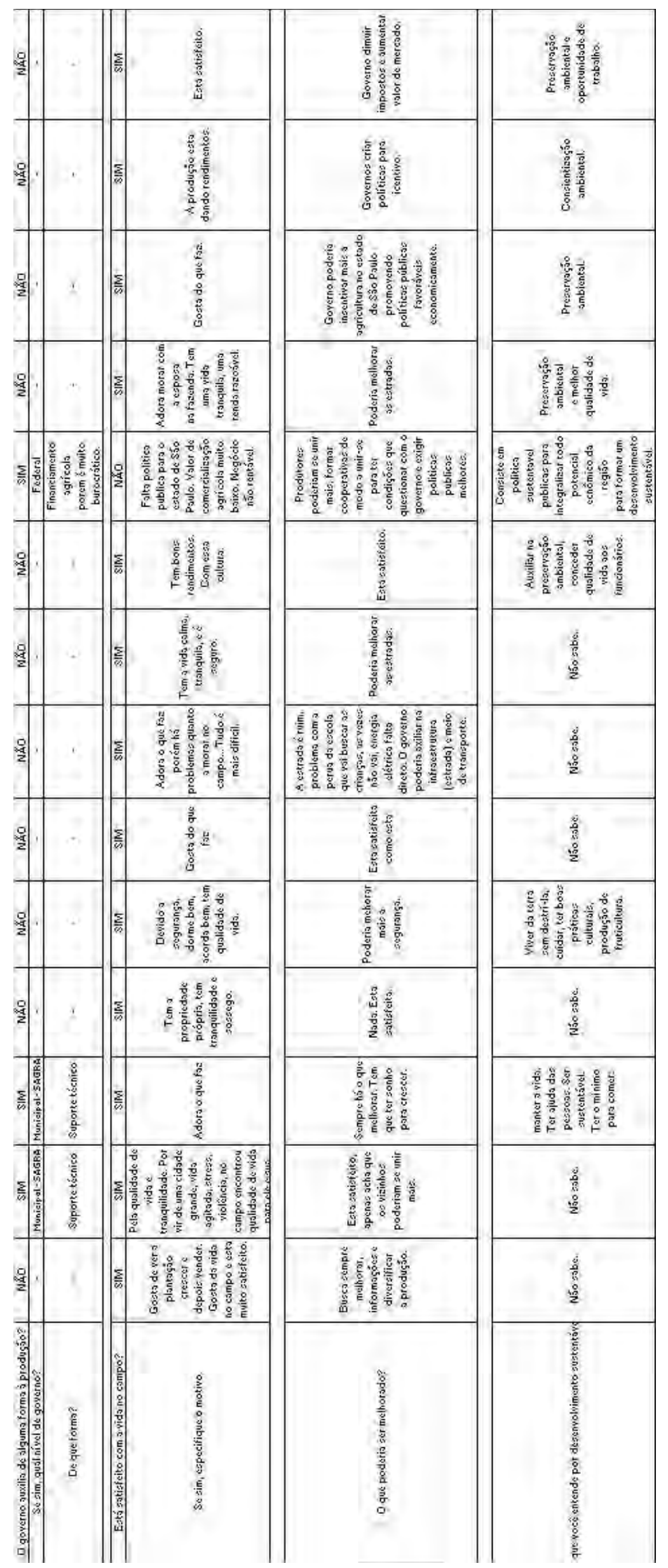

